\title{
Suppression of a Neocortical Potassium Channel Activity by Intracellular Amyloid- $\beta$ and Its Rescue with Homer 1a
}

\author{
Kenji Yamamoto, ${ }^{1,3}$ Yoshifumi Ueta, ${ }^{1}$ Li Wang, ${ }^{1,4}$ Ryo Yamamoto, ${ }^{1}$ Naoko Inoue, ${ }^{5}$ Kaoru Inokuchi, ${ }^{5}$ Atsu Aiba, ${ }^{6}$ \\ Hideto Yonekura, ${ }^{2}$ and Nobuo Kato ${ }^{1}$ \\ Departments of ${ }^{1}$ Physiology and ${ }^{2}$ Biochemistry, Kanazawa Medical University, Ishikawa 920-0293, Japan, ${ }^{3}$ Clinical Research Center and Department of \\ Neurology, Utano National Hospital, Kyoto 616-8255, Japan, ${ }^{4}$ China-Japan Friendship Hospital, Beijing 100029, China, ${ }^{5}$ Mitsubishi Kagaku Institute of Life \\ Sciences, Tokyo 194-8511, Japan, and ${ }^{6}$ Department of Molecular and Cellular Biology, Kobe University Graduate School of Medicine, Kobe 650-0017, Japan
}

It is proposed that intracellular amyloid- $\beta(\mathrm{A} \beta)$, before extracellular plaque formation, triggers cognitive deficits in Alzheimer disease (AD). Here we report how intracellular $\mathrm{A} \beta$ affects neuronal properties. This was done by injecting $\mathrm{A} \beta$ protein into rat and mouse neocortical pyramidal cells through whole-cell patch pipettes and by using $3 \times \mathrm{Tg}$ AD model mice, in which intracellular A $\beta$ is accumulated innately. In rats, intracellular application of a mixed $\mathrm{A} \beta_{1-42}$ preparation containing both oligomers and monomers, but not a monomeric preparation of $\mathrm{A} \beta_{1-40}$, broadened spike width and augmented $\mathrm{Ca}^{2+}$ influx via voltage-dependent $\mathrm{Ca}^{2+}$ channels in neocortical neurons. Both effects were mimicked and occluded by charybdotoxin, a blocker of large-conductance $\mathrm{Ca}^{2+}$-activated $\mathrm{K}^{+}$(BK) channels, and blocked by isopimaric acid, a BK channel opener. Surprisingly, augmented $\mathrm{Ca}^{2+}$ influx was caused by elongated spike duration, but not attributable to direct $\mathrm{Ca}^{2+}$ channel modulation by $\mathrm{A} \beta_{1-42}$. The $\mathrm{A} \beta_{1-42}$-induced spike broadening was blocked by electroconvulsive shock (ECS), which we previously showed to facilitate BK channel opening via expression of the scaffold protein Homerla. In young 3xTg and wild mice, we confirmed spike broadening by $\mathrm{A} \beta_{1-42}$, which was again mimicked and occluded by charybdotoxin and blocked by ECS. In Homer 1a knock-out mice, ECS failed to block the $\mathrm{A} \beta_{1-42}$ effect. Single-channel recording on BK channels supported these results. These findings suggest that the suppression of $\mathrm{BK}$ channels by intracellular $\mathrm{A} \beta_{1-42}$ is a possible key mechanism for early dysfunction in the $\mathrm{AD}$ brain, which may be counteracted by activity-dependent expression of Homerla.

\section{Introduction}

Amyloid- $\beta(\mathrm{A} \beta)$ is the main component of senile plaque, which pathologically characterizes Alzheimer's disease (AD). The accumulation of $\mathrm{A} \beta$ precedes other pathological features of $\mathrm{AD}$ such as tangle formation and cell death. Recently, however, soluble A $\beta$ rather than $\mathrm{A} \beta$ plaque has been considered to be toxic, causing synaptic dysfunction or loss before plaque appears (Hsia et al., 1999; Hardy and Selkoe, 2002). Extracellularly applied A $\beta$ suppresses synaptic transmission and induces synaptic loss by interacting with surface receptors including nicotinic acetylcholine and glutamate receptors (Wang et al., 2000; Kamenetz et al., 2003; Snyder et al., 2005), receptors for advanced glycation end

Received Dec. 25, 2010; revised April 18, 2011; accepted May 22, 2011.

Author contributions: K.Y. and N.K. designed research; K.Y., Y.U., L.W., R.Y., and N.K. performed research; N.I., K.I., and A.A. contributed unpublished reagents/analytic tools; K.Y., Y.U., L.W., H.Y., and N.K. analyzed data; K.Y. and N.K. wrote the paper.

This work was supported by grants for Collaborative Research (C2006-5, (2007-2) and High-Tech Research (H2008-14, H2009-14, and H2010-14) from Kanazawa Medical University, and a grant from the Science Research Promotion Fund of the Promotion and Mutual Aid Corporation for Private Schools of Japan to N.K. We express our gratitude to Dr. F. M. LaFerla (University of California, Irvine, CA) for providing mice and to Dr. H. Kawai (Soka University, Tokyo, Japan) and Dr. Y. Ohyagi (Kyushu University, Fukuoka, Japan) for advice. We also thank S. Muramoto, H. Adachi, and K. Yamada for technical and secretarial assistance.

Correspondence should be addressed to Nobuo Kato, Department of Physiology, Kanazawa Medical University, Ishikawa 920-0293, Japan. E-mail: kato@kanazawa-med.ac.jp.

K. Inokuchi's present address: Graduate School of Medicine \& Pharmaceutical Sciences, University of Toyama, Toyama 930-0194, Japan.

DOI:10.1523/JNEUROSCI.6752-10.2011

Copyright $\odot 2011$ the authors $\quad 0270-6474 / 11 / 3111100-10 \$ 15.00 / 0$ product (RAGE) (Deane et al., 2003; Origlia et al., 2008), and cellular prion protein (Laurén et al., 2009).

Besides extracellular $A \beta$, intracellular accumulation of $A \beta$ is reported in postmortem AD brain (Gouras et al., 2000; Takahashi et al., 2002) and model mice (Oddo et al., 2003; Billings et al., 2005). Its intracellular presence seems to be a prerequisite for its secretion from neurons (Walsh et al., 2002; Abramov et al., 2009; Wei et al., 2010). Intracellular $A \beta$ is present both in late endosome (Takahashi et al., 2002) and cytoplasm (LaFerla et al., 2007) and is regarded as one of the early pathological events in AD (LaFerla et al., 2007). Indeed, mutation of SORL1, a risk gene for sporadic $\mathrm{AD}$, is shown to elevate the intracellular $\mathrm{A} \beta$ level (Rogaeva et al., 2007). As with extracellular $A \beta$, intracellular $A \beta$ may interfere with channels and receptors regulating fundamental neuronal characteristics such as excitability and synaptic plasticity.

In $\mathrm{AD}$ patients, motor cortex excitability is increased (Ferreri et al., 2003). Extracellular A $\beta$ enhances release probability at hippocampal synapses, increasing neuron network activity in vitro (Abramov et al., 2009). Since neuronal activities promote the production of A $\beta$ (Kamenetz et al., 2003; Cirrito et al., 2005), a positive-feedback exacerbation of $\mathrm{A} \beta$ production and excitability is likely to result. However, there is another scenario, along which extracellular $\mathrm{A} \beta$ produced by neural activity can depress synaptic transmission (Kamenetz et al., 2003) and decreases synapse number (Wei et al., 2010), thereby reducing neuronal excitability. Reduced activity would decrease $\mathrm{A} \beta$ production, hence forming a 
negative-feedback regulation of excitability. In contrast to these well documented effects of extracellular $\mathrm{A} \beta$ on neuronal excitability, intracellular $A \beta$ has not been investigated in this particular light to date, which the present report seeks.

$\mathrm{Ca}^{2+}$-activated $\mathrm{K}^{+}$channels are well known to critically regulate spike firing in central neurons (Hu et al., 2001; Faber and Sah, 2003; Yu et al., 2010). We have reported that these $\mathrm{K}^{+}$channels are involved in regulation of neocortex pyramidal cell excitability by using intracellular injection of bioactive molecules through patch pipettes (Yamamoto et al., 2000, 2002a,b, 2005; Yamada et al., 2004; Sakagami et al., 2005). Here we apply the same methodology for elucidating how intracellularly injected $\mathrm{A} \beta$ perturbs excitability regulation involving $\mathrm{Ca}^{2+}$-activated $\mathrm{K}^{+}$channels.

\section{Materials and Methods}

Slice preparations. All experiments were performed in accordance with the guiding principle of the Physiological Society of Japan and with the approval of the Animal Care Committee of Kanazawa Medical University. Wistar rats [postnatal day 16 (P16) to P18], C57BL/6 wild mice (P16-P19), Homer1a knock-out mice (H1aKO mice; P16-P19) (Inoue et al., 2009), 4-month-old 3xTg mice (Oddo et al., 2003), and 3xTg mice at P16-P18 (3xTgj) were used. Animals of either sex were decapitated under ether anesthesia. The brain was dissected out and immersed in a bathing medium $\left(\mathrm{pH} 7.4 ; 2-5^{\circ} \mathrm{C}\right)$ containing (in mM) $124 \mathrm{NaCl}, 3.3 \mathrm{KCl}, 1.3 \mathrm{NaH}_{2} \mathrm{PO}_{4}, 26 \mathrm{NaHCO}_{3}, 2.5 \mathrm{CaCl}_{2}, 2.0$ $\mathrm{MgSO}_{4}$, and 20 glucose. Slices of the visual cortex were prepared with a microslicer DTK1000 at $200 \mu \mathrm{m}$ (Dosaka). In addition, frontal cortex slices were also made for comparison purposes.

Electroconvulsive shock. Electrical stimulations were performed as described previously (Sakagami et al., 2005; Yamamoto et al., 2005). Two volleys of alternating current $(90 \mathrm{~V}, 1 \mathrm{~s})$ were applied intracellularly at an interval of $5 \mathrm{~min}$. On passing the current, the whole body of the animal became rigid. At 10-20 s after the first volley, tonic-clonic seizure started and lasted for 20-40 s. After the second volley, a milder seizure lasting for a shorter time was observed. Within $30 \mathrm{~min}$, animals looked as normal as before the volleys. Animals were killed at $30 \mathrm{~min}$ after the shock, and slices were then cut in the same way as described for naive animals. We started recordings within $5 \mathrm{~h}$ because the expression level of Homerla protein gradually increases during this period (Brakeman et al., 1997).

Electrophysiological recordings. Slices were placed in a recording chamber on the stage of an upright microscope (BHWI; Olympus) with a $40 \times$ water-immersion objective (WPlanFl 40xUV). The chamber was continuously perfused with the bathing medium $\left(25^{\circ} \mathrm{C}\right)$ bubbled with a mixture of $95 \% \mathrm{O}_{2}$ and $5 \% \mathrm{CO}_{2}$. For recording, we used patch pipettes (resistance, 4-10 M $\Omega$ ) filled with a solution ( $\mathrm{pH} 7.3$ ) containing (in $\mathrm{mM}$ ) 7 $\mathrm{KCl}, 144 \mathrm{~K}$-gluconate, $10 \mathrm{KOH}$, and 10 HEPES. Whole-cell recordings were made from layer II/III pyramidal cells that had sufficiently negative resting membrane potentials (more negative than $-55 \mathrm{mV}$ ) without spontaneous action potentials. Membrane potentials were recorded in the current-clamp mode (Axopatch 1D or 200A; Molecular Devices) and digitized at $10 \mathrm{kHz}$ (Digidata 1200 or 1440 and pCLAMP10; Molecular Devices). The width of evoked spikes was measured to assess BK channel activities. For eliciting spikes, brief depolarization currents ( $0.45 \mathrm{nA}, 10$ $\mathrm{ms}$ in rats; $0.7 \mathrm{nA}, 5 \mathrm{~ms}$ in mice; with occasional minor fine adjustments) were injected through the patch pipette adjusted to allow just a single spike during each pulse (four spikes at $18 \mathrm{~Hz}$ in rats, five spikes at $100 \mathrm{~Hz}$ in mice). Spike half-widths were measured at $50 \%$ of the peak.

For recording $\mathrm{Ca}^{2+}$ currents under voltage clamp (see Fig. 4), tetrodotoxin ( $1 \mu \mathrm{M}$; Sigma) and tetraethylammonium chloride (TEA; $20 \mathrm{~mm}$; Nacalai) were added to the bathing medium; patch pipettes were filled with a Cs-based solution, to block $\mathrm{K}^{+}$channels ( $\mathrm{pH}$ 7.3), containing (in mM) 133 Cs-gluconate, 6 CsCl, 9 TEA, 9 HEPES, and 5 QX-314. Ca ${ }^{2+}$ currents induced by step depolarizations from $-70 \mathrm{mV}$ (holding potential) to $-50,-30,-10$, and $+10 \mathrm{mV}$ for $200 \mathrm{~ms}$ were recorded in the voltage-clamp mode. Single BK currents were induced by ramp-voltage command from +100 to $-100 \mathrm{mV}$ or by step command from 0 to +40 $\mathrm{mV}$ that were applied to cell-attached mode using a pipette solution containing $140 \mathrm{KCl}, 10 \mathrm{HEPES}, 2 \mathrm{MgCl}_{2}, 20$ glucose, and $10 \mathrm{CaCl}_{2}$. Since we were aware that ECS-induced facilitation of BK channels depends critically on intracellular signaling involving Homerla and other molecules (Sakagami et al., 2005), cell-attached recording was adopted to minimize damage to the molecular cascade involved. After cell-attached patch, the bathing medium was replaced by the same solution as pipette solution before starting single BK channel recording.

$\mathrm{Ca}^{2+}$ photometry. Fluorometry was performed as described (Yamamoto et al., 2002a,b, 2005). Briefly, fura-2 (0.2 mm; Dojindo Ltd.) was loaded for at least $5 \mathrm{~min}$ after whole-cell breakin. A photomultiplier (OSP-10; Olympus) attached to the microscope (BHWI; Olympus) was used to measure spike-induced $\mathrm{Ca}^{2+}$ signals from the soma. A train of four spikes was evoked by brief depolarizing currents at the initial phase of the measurement, which lasted for $5 \mathrm{~s}$ in total for each trial. Fluorescence signals excited at $360 \mathrm{~nm}$ were measured without current injections. We defined $-\Delta F_{380} / F_{360}$ as the index with which to estimate absolute changes in the $\mathrm{Ca}^{2+}$ concentration (Isomura and Kato, 1999). In this formula, $\Delta F_{380}$ is the difference between the $380 \mathrm{~nm}$ excited fluorescence intensity $\left(F_{380}\right)$ in the resting state and the fluorescence intensity at a given time during the trial, and $F_{360}$ is the $360 \mathrm{~nm}$ excited fluorescence intensity measured shortly before the test measurement with $380 \mathrm{~nm}$ excited fluorescence. All the $\mathrm{Ca}^{2+}$ increases were expressed in units of $-\Delta F_{380} / F_{360}$. $\mathrm{Ca}^{2+}$ increases induced by the four-spike trial were averaged over three trials to provide the data plots shown in the figures.

Drugs used. Depending on the purpose of the experiments, cyclopiazonic acid (CPA; $30 \mu \mathrm{M})$, nimodipine $(20 \mu \mathrm{M})$, charybdotoxin (Chtx; 50 $\mathrm{nM}$ ), 4-aminopyridine (4-AP; $5 \mathrm{~mm}$ ), and isopimaric acid (Iso; $10 \mu \mathrm{M}$ ) (all purchased from Sigma) were applied into the bathing medium. Recombinant $\mathrm{A} \beta_{1-42}$ (1 or $10 \mu \mathrm{M}$; Sigma), $\mathrm{A} \beta_{1-40}(10 \mu \mathrm{M}$; Sigma), or rabbit polyclonal anti-Homer la antibodies $[0.4 \mu \mathrm{g} / \mathrm{ml}$, as described previously by Kato et al. (1997)] were contained in the patch pipette internal solution and distributed into the cell by diffusion (infusion), for at least $5 \mathrm{~min}$ after whole-cell breakin, before the recording session was started. In some experiments, recombinant $\mathrm{A} \beta_{1-42}(1 \mu \mathrm{M})$ was applied extracellularly.

Gel electrophoresis. The aggregation state of $\mathrm{A} \beta_{1-42}$ and $\mathrm{A} \beta_{1-40}$ in the pipette solution was assessed by tricine-SDS-PAGE (Schägger, 2006). Samples were taken from each $\mathrm{A} \beta$ dissolved in the pipette solution and added to SDS loading buffer (50 mM Tris/HCl, pH 6.8, 4\% SDS, 1.0 $\mathrm{mg} / \mathrm{ml}$ bromophenol blue, $20 \%$ glycerol, and 10\% 2-mercaptoethanol). The mixture was separated by tricine-SDS gel electrophoresis $(16.5 \%$ polyacrylamide) and stained with Coomassie Blue. Before loading, samples were heated at $40^{\circ} \mathrm{C}$ for $30 \mathrm{~min}$ or $95^{\circ} \mathrm{C}$ for 5 min $[$ Heat $(+)]$ for control or left without heating $[$ Heat $(-)]$ for the test. For density profiling, the Plot Lanes function in ImageJ software (1.42q) was used under the default setting. The density on scanned gel images was calculated and expressed in an arbitrary unit for each lane, so that densities of bands, if any exist, can be expressed relative to the most dense monomer band.

Data analysis. Data are expressed as mean \pm SEM. Paired or unpaired $t$ tests were used for parametric statistics. Statistical tests for $\mathrm{Ca}^{2+}$ currents were made by using the peak values (evoked by the voltage step from -70 to $-10 \mathrm{mV}$ ).

\section{Results}

\section{Intracellular injection of $\mathrm{A} \boldsymbol{\beta}_{1-42}$ broadens spike width and augmented spike-induced $\mathrm{Ca}^{2+}$ influx by suppressing BK channels in neocortical neurons}

Whole-cell recordings were made from pyramidal neurons located in layer II/III of the rat visual cortex in slices. To elucidate pathophysiological changes in neuronal activity induced by intracellular $\mathrm{A} \beta$, recombinant $\mathrm{A} \beta_{1-42}$ or $\mathrm{A} \beta_{1-40}$ and $\mathrm{Ca}^{2+}$ indicator fura- 2 were infused intracellularly from the patch pipette. Membrane potentials and spike-induced intracellular $\mathrm{Ca}^{2+}$ increases were simultaneously recorded in the current-clamp mode during a train of four action potentials. To elicit the spikes, four pulses of depolarizing currents were injected through the patch pipette at $18 \mathrm{~Hz}$ (Fig. 1C, inset). The choice of this frequency was based on our previous experiments (Yamamoto et al., 2002, 2005). In $\mathrm{A} \beta_{1-42}$-injected neurons ( $10 \mu \mathrm{M}$, red), spike width was broadened 
compared with "control" neurons that had no A $\beta$ injected (black) (Fig. $1 A$ ). The averaged spike half-width in $A \beta_{1-42^{-}}$ injected neurons (first spike, $1.78 \pm 0.06$ $\mathrm{ms}$; fourth spike, $2.42 \pm 0.10 \mathrm{~ms} ; n=6$ ) (Fig. $1 B$ ) was significantly longer than that in control neurons (first spike: $1.25 \pm$ $0.07 \mathrm{~ms}, p<0.0005$; fourth spike: $1.36 \pm$ $0.10 \mathrm{~ms}, p<0.0001 ; n=6$ ) (Fig. $1 B$ ). The enhancement was sufficiently significant at the fourth spike with $1 \mu \mathrm{M} \mathrm{A} \beta_{1-42}$ $(1.76 \pm 0.14 \mathrm{~ms} ; p<0.001 ; n=6)$. In contrast to $A \beta_{1-42}$, intracellular injection of $10 \mu \mathrm{M} \mathrm{A} \beta_{1-40}$ did not change spike halfwidth (first spike, $1.17 \pm 0.03 \mathrm{~ms}$; fourth spike, $1.34 \pm 0.09 \mathrm{~ms} ; n=6$ ) (Fig. $1 A, B$ ). Moreover, resting membrane potential was not significantly different among these neurons (control, $-59 \pm 2 \mathrm{mV} ; 10$ $\mu \mathrm{M} \mathrm{A} \beta_{1-42},-59 \pm 1 \mathrm{mV} ; 10 \mu \mathrm{M} \mathrm{A} \beta_{1-40}$, $-59 \pm 1 \mathrm{mV})$. It is thus shown that intracellular $\mathrm{A} \beta_{1-42}$, but not $\mathrm{A} \beta_{1-40}$, broadens spike width during spike trains without changing membrane potential.

Caution should be exercised, however, in assigning this result to different toxicity levels between $\mathrm{A} \beta_{1-42}$ and $\mathrm{A} \beta_{1-40}$ per se, given that the vulnerability to oligomerization differs between the two forms of $\mathrm{A} \beta$ (Stine et al., 2003) and the oligomerization state is a major determinant of $\mathrm{A} \beta$ toxicity (for review, see LaFerla et al., 2007). Thus, we briefly checked what assembly states $A \beta_{1-42}$ and $A \beta_{1-40}$ actually take in our pipette solution. Gel electrophoresis (SDS-PAGE) showed that the vast majority of $\mathrm{A} \beta_{1-42}$ took the monomer form and also contained far lower concentrations of trimer and tetramer (Fig. 2). This $\mathrm{A} \beta_{1-42}$ composition is in broad agreement with that of the unaggregated sample described by Stine et al. (2003). On the other hand, $\mathrm{A} \beta_{1-40}$ preparation consisted of monomers (Fig. 2). These findings indicate that intracellular injection of a mixed $\mathrm{A} \beta_{1-42}$ preparation consisting of monomers and oligomers, but not a monomeric preparation of $\mathrm{A} \beta_{1-40}$, is effective in broadening spikes in the present experiments (Fig. 1). Our mixed $A \beta_{1-42}$ preparation showed a significant spikebroadening effect at the concentration of $1 \mu \mathrm{M}$. If $\mathrm{A} \beta_{1-42}$ oligomers, but not monomers, are responsible for this effect, the effective concentration range of $\mathrm{A} \beta_{1-42}$ oligomers should be far less than $1 \mu \mathrm{M}$, given the relative concentration profile of monomers and oligomers in this mixture (Fig. $2 B)$. Also, it has to be considered that the intracellular concentration of the $\mathrm{A} \beta_{1-42}$ mixture in the present experiments is lower than that in the pipette solution, since the $\mathrm{A} \beta_{1-42}$ mixture was injected by perfusion. Overall, in terms of the effective intracellular concentration of $\mathrm{A} \beta_{1-42}$ oligomers, the present finding
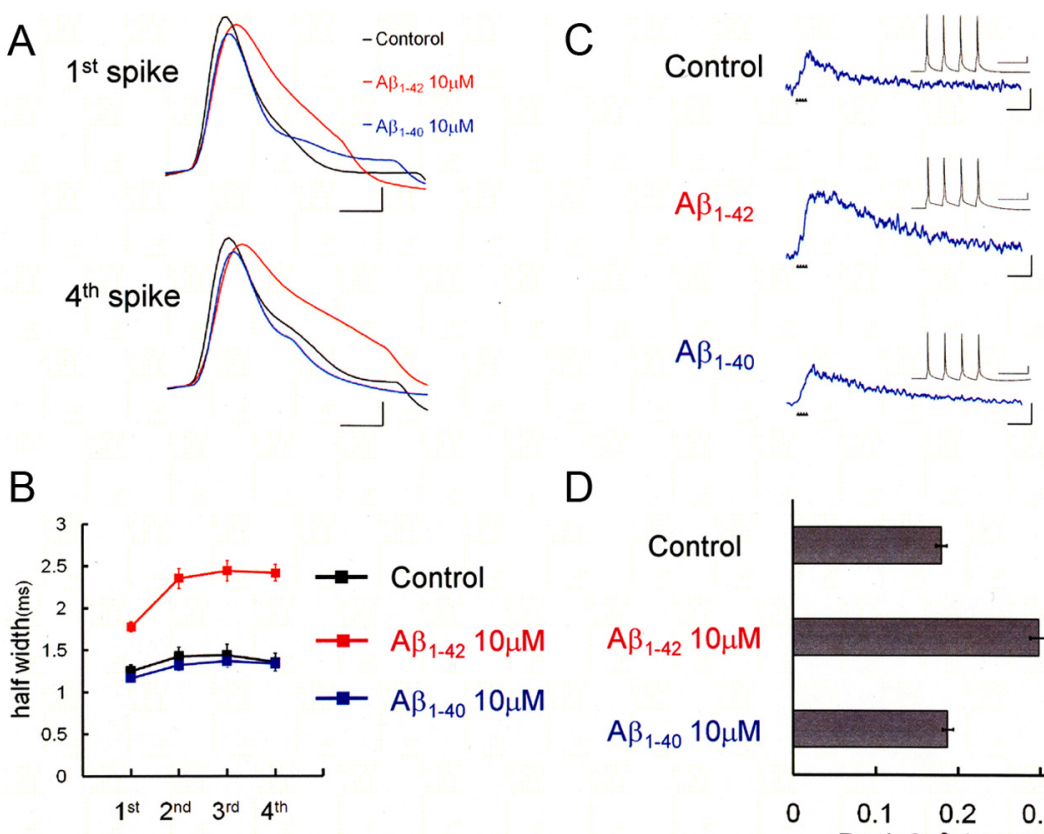

Figure 1. Intracellular infusion of $A \beta_{1-42}$ broadens spike width and augmented $\mathrm{Ca}^{2+}$ influx in rat neocortical pyramidal neurons. $A$, Action potentials evoked in neurons injected with $A \beta$. The first and fourth action potentials in spike trains are shown. Recordings taken from the control neuron (black), an $A \beta_{1-42}$-injected neuron (red), and an $A \beta_{1-40}$-injected neuron (blue) are superimposed to clarify the spike broadening in $A \beta_{1-42}$-injected neurons. Calibration: $1 \mathrm{~ms}, 20 \mathrm{mV}$. $\boldsymbol{B}$, Average spike half-width in four-spike trains, showing that injection of $A \beta_{1-42}(10 \mu \mathrm{m}$; red square; $n=6)$, but not that of $A \beta_{1-40}(10 \mu \mathrm{m} ;$ blue square; $n=6)$, broadened spike width compared with control neurons (black square; $n=6) . C, \mathrm{Ca}^{2+}$ increases induced by four-spike trains (inset) in control neurons and in neurons injected with $10 \mu \mathrm{mA} \beta_{1-42}$ or $10 \mu \mathrm{MA} \beta_{1-40}$. Calibration: $500 \mathrm{~ms},-0.1 \Delta F_{380} / F_{360}$. Inset, Specimen recording of a spike train at $18 \mathrm{~Hz}$ that was used for the shown $\mathrm{Ca}^{2+}$ measurements. The timing of each spike is shown by a small black triangle below the trace. Note the difference in time scale. Calibration: $100 \mathrm{~ms}, 20 \mathrm{mV}$. D, Summary diagram demonstrating average $\mathrm{Ca}^{2+}$ increases. Injection of $\mathrm{A} \beta_{1-42}$ enhanced spike-induced $\mathrm{Ca}^{2+}$ increases. ${ }^{*} p<0.0001$.

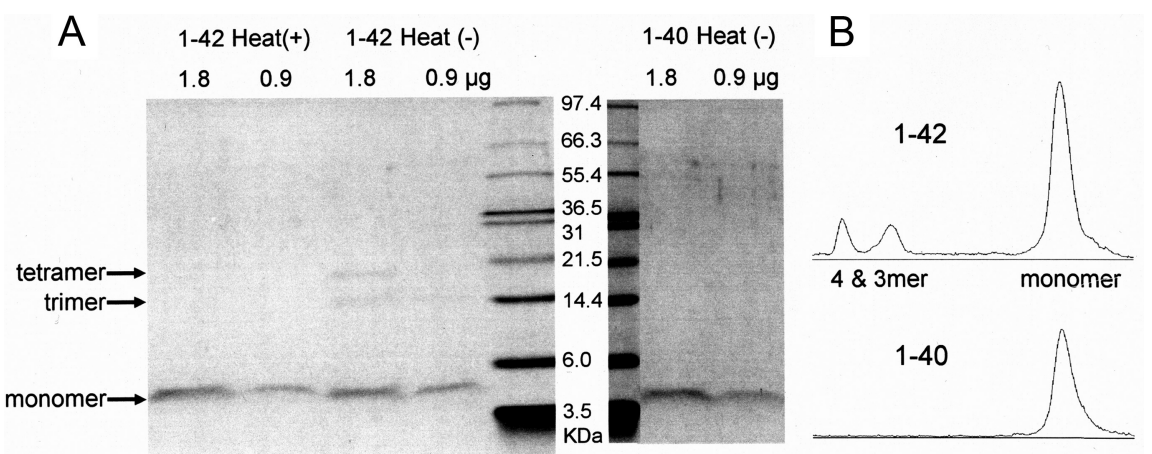

Figure 2. Detection of $A \beta_{1-42}$ oligomers in the pipette solution. $A, A \beta_{1-42}$ and $A \beta_{1-40}$ were taken from the pipette solution and prepared for SDS-PAGE. Two different amounts (1.8 and $0.9 \mu \mathrm{g}$ ) were used. Samples were heated [Heat $(+)$ ] before loading for controls or left without heating [Heat $(-)]$. Based on the molecular-weight marker, the positions for monomer, trimer, and tetramer were determined. For $A \beta_{1-42}$ only, in addition to the monomer, bands are also positive at the trimer and tetramer positions, albeit to much lesser extents than the monomer band [1-42 Heat $(-), 1.8 \mu \mathrm{g}]$. B, Band density profiles. By applying the Plot Lanes function (ImageJ software) to scanned gel images, density profiles were drawn for the lanes loaded with unheated $A \beta_{1-42}[1-42$ Heat $(-), 1.8 \mu \mathrm{g}]$ and $A \beta_{1-40}[1-40$ Heat $(-), 1.8 \mu \mathrm{g}]$. Relative optical density was plotted in an arbitrary unit for each lane. The top-to-bottom direction in the lane is reflected to the left-to-right direction in this diagram. Compared with the peak density for the monomer band, those for trimer and tetramer were much lower for $A \beta_{1-42}$ and undetectable for $A \beta_{1-40}$.

seems to be consistent with the report that intracellular injection of $10-100 \mathrm{nM} \mathrm{A} \beta_{1-42}$ oligomer suppresses synaptic transmission in squid giant axons (Moreno et al., 2009).

Spike broadening is supposed to increase $\mathrm{Ca}^{2+}$ influx (Llinás et al., 1982). We therefore measured changes in intracellular $\mathrm{Ca}^{2+}$ concentration during the four-spike train with or without $\mathrm{A} \beta_{1-42}$ injected. Indeed, spike-induced $\mathrm{Ca}^{2+}$ increases during the 
A

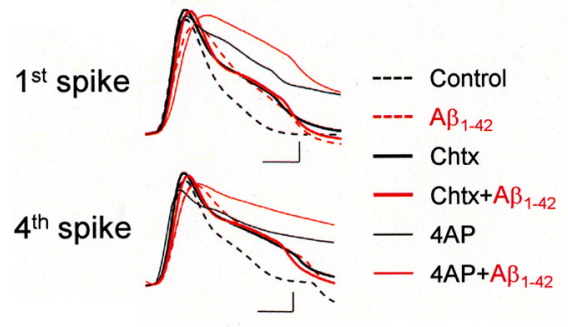

B

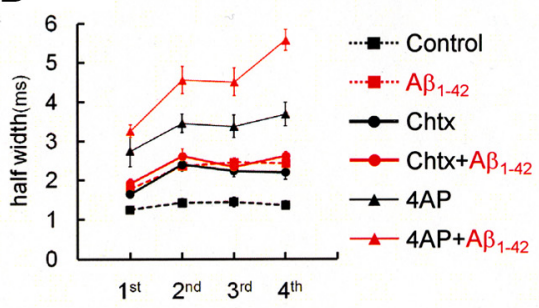

C

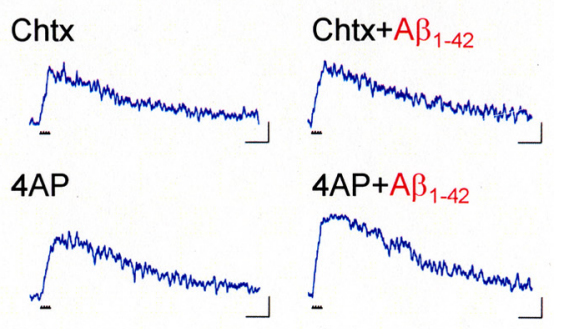

$\mathrm{D}$

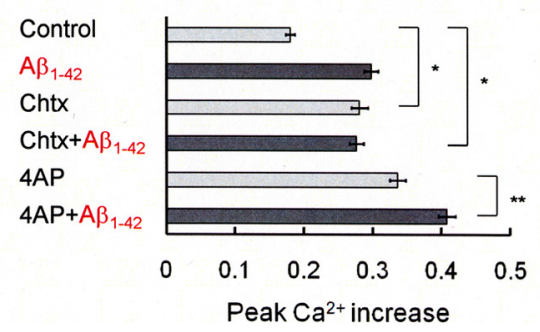

Figure 3. Intracellular $A \beta_{1-42}$ enlarges spike width by suppressing $B K$ channels, thereby increasing spike-induced $\mathrm{Ca}^{2+}$ entry. $A$, First and fourth action potentials during spike trains after application of the BK channel blocker Chtx (50 nm) or the A-type $\mathrm{K}^{+}$ channel blocker 4-AP (5 mM) in a control cell (Chtx: thick black trace, $n=7 ; 4-A P$ : thin black trace, $n=5)$ and an A $\beta_{1-42}$-injected cell ( $C h t x+A \beta_{1-42}$ : thick red trace, $n=4 ; 4-A P+A \beta_{1-42}$ : thin red trace, $\left.n=4\right)$. The action potentials in the control cell (black dashed trace) and $A \beta_{1-42}$-injected cell (red dashed trace) shown in Figure 1 are superimposed. Calibration: $1 \mathrm{~ms}, 20 \mathrm{mV} . \boldsymbol{B}$, Averaged spike half-width during four-spike trains with no blocker (black square, Control; red square, $A \beta_{1-42}$ ), with charybdotoxin (black circle, Control; red circle, $A \beta_{1-42}$ ) and with 4-AP (black triangle, Control; red triangle, $A \beta_{1-42}$ ). $C$, Spike-induced $C^{2+}$ increase under application of charybdotoxin or 4-AP in control or $A \beta_{1-42}$-injected neurons. Calibration: $500 \mathrm{~ms},-0.1 \Delta F_{380} / F_{360}$. $D$, Summary diagram demonstrating average $\mathrm{Ca}^{2+}$ increases in the control, charybdotoxin, and 4-AP groups, each with and without $A \beta_{1-42}$. In $B$ and $\boldsymbol{D}$, charybdotoxin, but not 4-AP, mimicked and occluded the effect of $A \beta_{1-42 \cdot}{ }^{*} p<0.0001 ;{ }^{* *} p<0.01$.

spike train were enhanced by $\mathrm{A} \beta_{1-42}$. Peak amplitude of the $\mathrm{Ca}^{2+}$ rise in $10 \mu \mathrm{M} \mathrm{A} \beta_{1-42}$ injected neurons was $0.30 \pm 0.01(n=6)$ in the unit of $-\Delta F_{380} / F_{360}$ and significantly larger than in control neurons $(0.18 \pm 0.01 ; p<0.0001 ; n=6)$ (Fig. $1 C, D)$. As with the spike broadening, the enhancement of $\mathrm{Ca}^{2+}$ increases was again sufficiently significant with $1 \mu \mathrm{M} \mathrm{A} \beta_{1-42}(0.25 \pm 0.01 ; p<0.001$; $n=6$ ). Intracellular injection of $10 \mu \mathrm{M} \mathrm{A} \beta_{1-40}$ did not change spike-induced $\mathrm{Ca}^{2+}$ rise $(0.19 \pm 0.01 ; n=6)$ (Fig. $\left.1 C, D\right)$. Thus, these results indicate that intracellular $A \beta_{1-42}$ broadens spike width during spike trains, thereby enhancing spike-induced $\mathrm{Ca}^{2+}$ increase.

To determine the mechanism of spike broadening, we focused on large-conductance, $\mathrm{Ca}^{2+}$-activated $\mathrm{K}^{+}$channels (BK channels) and A-type $\mathrm{K}^{+}$channels (Fig. 3), because blocking either of these channels is known to enhance spike width and intracellular $\mathrm{Ca}^{2+}$ influx in central neurons (Shao et al., 1999; Faber and Sah., 2003). The BK channel blocker Chtx (50 nM), applied alone, broadened spike half-width to the same extent as the injection of $10 \mu \mathrm{M}$ $\mathrm{A} \beta_{1-42}$, with the width significantly greater than no-Chtx control (first spike: $1.64 \pm 0.10 \mathrm{~ms}, p<0.01$; fourth spike: $2.19 \pm 0.17$ $\mathrm{ms}, p<0.01 ; n=7)$. Also, the application of A-type $\mathrm{K}^{+}$channel blocker 4-AP (5 mM) broadened spike half-width without $\mathrm{A} \beta_{1-42}$ infused (first spike, $2.74 \pm 0.39 \mathrm{~ms}$; fourth spike, $3.68 \pm 0.30 \mathrm{~ms} ; n=$ 4). However, when combined with intracellular $\mathrm{A} \beta_{1-42}$, effects of the two blockers were different. The application of charybdotoxin combined with infused $\mathrm{A} \beta_{1-42}$ did not augment spike half-width any further, exhibiting occlusion of the two effects (first spike, $1.91 \pm$ $0.11 \mathrm{~ms}$; fourth spike, $2.59 \pm 0.12 \mathrm{~ms} ; n=5$ ). In contrast, combined application of 4-AP and $\mathrm{A} \beta_{1-42}$ increased spike half-width to a significantly greater extent than 4-AP alone (fourth spike: $5.56 \pm 0.27$ $\mathrm{ms}, p<0.01 ; n=4)($ Fig. $3 A, B)$, indicating that the two effects were additive.
The effects of charybdotoxin and $\mathrm{A} \beta_{1-42}$ were occluded also in spikeinduced $\mathrm{Ca}^{2+}$ increase, whereas the effects of 4-AP and $\mathrm{A} \beta_{1-42}$ were again additive (Fig. $3 C, D$ ). Peak amplitude of the $\mathrm{Ca}^{2+}$ rise with charybdotoxin alone was $0.28 \pm 0.01(n=7)$, which was significantly larger than in control neurons $(p<0.0001)$ and almost the same as with $10 \mu \mathrm{M} \mathrm{A} \beta_{1-42}$ injection. Combined application of charybdotoxin and $A \beta_{1-42}$ did not significantly enhance $\mathrm{Ca}^{2+}$ increase any further $(0.28 \pm 0.01 ; n=5)$ than did charybdotoxin alone and was significantly larger than in control neurons $(p<$ 0.0001 ). In contrast with charybdotoxin, the application of 4-AP combined with the infusion of $\mathrm{A} \beta_{1-42}$ augmented $\mathrm{Ca}^{2+}$ rise $(0.41 \pm 0.01 ; n=4)$ significantly greater than 4-AP alone $(0.34 \pm 0.01 ; p<0.01 ; n=$ 4) (Fig. $3 C, D$ ). The results with currentclamp recording and $\mathrm{Ca}^{2+}$ fluorometry combined together (Fig. 3) indicate that charybdotoxin, but not 4-AP, mimics and occludes spike broadening and spikeinduced $\mathrm{Ca}^{2+}$ increase by intracellular $\mathrm{A} \beta_{1}$. 42. These findings suggest that $B K$ channels are responsible for the present $A \beta_{1-42^{-}}$ induced spike broadening, which prolongs depolarization during spikes and thereby enhances $\mathrm{Ca}^{2+}$ influx through voltagedependent $\mathrm{Ca}^{2+}$ channels (VDCCs).

\section{$\mathrm{A} \boldsymbol{\beta}_{1-42}$ indirectly increases $\mathrm{Ca}^{2+}$ influx by means of $\mathrm{BK}$ channel suppression}

Our results so far indicate that $A \beta_{1-42}$ suppresses $B K$ channel activity and thereby elongates depolarization time during individual spikes, which eventually activates $\mathrm{Ca}^{2+}$ channels longer to cause the larger $\mathrm{Ca}^{2+}$ influx. However, direct modulation of $\mathrm{Ca}^{2+}$ channels by intracellular $\mathrm{A} \beta_{1-42}$ is still possible. Given that extracellular A $\beta$ modulates VDCC (Ueda et al., 1997; MacManus et al., 2000) and APP directly binds and modulates VDCC (Yang et al., 2009), intracellular $A \beta$ could directly upregulate VDCC and enhance $\mathrm{Ca}^{2+}$ influx, independently of BK channels. To test this possibility, voltage-activated $\mathrm{Ca}^{2+}$ currents were measured. In voltage-clamp experiments, voltage steps from the holding voltage of $-70 \mathrm{mV}$ to various depolarized voltages were imposed with or without $\mathrm{A} \beta_{1-42}$ infused (Fig. $4 A, B$ ). The injection of $\mathrm{A} \beta_{1-}$ 42 , however, has no effect on $\mathrm{Ca}^{2+}$ current; the peak $\mathrm{Ca}^{2+}$ current evoked by the voltage step from -70 to $-10 \mathrm{mV}$ was $1.69 \pm 0.05$ $\mathrm{nA}(n=7)$ in $\mathrm{A} \beta_{1-42}$-injected neurons, which was not significantly different from $1.72 \pm 0.08 \mathrm{nA}$ in control neurons $(n=10)$.

Another potential $\mathrm{Ca}^{2+}$ origin is $\mathrm{Ca}^{2+}$-releasing channels on $\mathrm{Ca}^{2+}$ store such as $\mathrm{IP}_{3}$ receptor or ryanodine receptor, since this $\mathrm{Ca}^{2+}$ source may also contribute to augment spike-induced $\mathrm{Ca}^{2+}$ increase (Yamamoto et al., 2000, 2002a,b). To rule out this possibility, we used the $\mathrm{Ca}^{2+}$ store depleter CPA $(30 \mu \mathrm{M})$. This blocker allowed the injected $A \beta_{1-42}$ to enhance $\mathrm{Ca}^{2+}$ increase (Fig. $\left.4 C, \mathrm{~A} \beta_{1-42}+\mathrm{CPA}\right)$. In $\mathrm{A} \beta_{1-42}$-injected neurons, the peak $\mathrm{Ca}^{2+}$ with CPA $(0.27 \pm 0.02 ; n=5)$ kept the same level as without $\mathrm{CPA}(0.25 \pm 0.01 ; n=6)$ and was significantly larger than in control neurons with CPA $(0.18 \pm 0.01 ; p<0.01 ; n=6)$ (Fig. $4 C, D$ ). In contrast, the VDCC blocker nimodipine prevented 
$\mathrm{A} \beta_{1-42}$ to enhance $\mathrm{Ca}^{2+}$ increase $(20 \mu \mathrm{M})$ (Fig. 4C, $\mathrm{A} \beta_{1-42}+$ Nimodipine). The peak $\mathrm{Ca}^{2+}$ increase with nimodipine applied alone was $0.14 \pm 0.01(n=5)$, which was not significantly different from that with nimodipine combined with $1 \mu \mathrm{M} \mathrm{A} \beta_{1-42}$ injection ( $0.14 \pm 0.01 ; n=5$ ) (Fig. $4 C, D$, Nimodipine). It is thus unlikely that intracellular $\mathrm{A} \beta_{1-42}$-mediated enhancement of $\mathrm{Ca}^{2+}$ increase depends on the direct upregulation of VDCC or $\mathrm{Ca}^{2+}$-releasing channels. These results together indicate that intracellular $\mathrm{A} \beta_{1-42}$ modulates $\mathrm{BK}$ channels first, thereby broadens spike width, and then opens VDCCs longer, finally leading to enhancement of spikeinduced $\mathrm{Ca}^{2+}$ influx without directly modulating VDCCs.

\section{Suppression of BK channels by}

\section{intracellular $A \boldsymbol{\beta}_{1-42}$ is counteracted via} Homerla in neocortical neurons Fura-2 is a $\mathrm{Ca}^{2+}$ chelator, which can affect intracellular $\mathrm{Ca}^{2+}$ dynamics and modify the kinetics of BK channels, that is $\mathrm{Ca}^{2+}$ dependent. To eliminate the effect of fura- 2 and determine the effect of $\mathrm{A} \beta_{1-42}$ itself, we next performed the whole-cell recording without fura- 2 in the patch pipette. In this case, intracellular $A \beta_{1-42}(10$ $\mu \mathrm{M})$ again significantly enhanced spike half-width (first spike, $1.83 \pm 0.12 \mathrm{~ms}$; fourth spike, $2.40 \pm 0.26$ $\mathrm{ms} ; n=5$ ) compared with intracellular $\mathrm{A} \beta_{1-40}$ (first spike: $1.23 \pm$ $0.05 \mathrm{~ms}, p<0.01$; fourth spike: $1.42 \pm 0.14 \mathrm{~ms}, p<0.02 ; n=7$ ) or no $\mathrm{A} \beta$ infused (first spike, $1.24 \pm 0.06 \mathrm{~ms}, p<0.01$; fourth spike, $1.52 \pm 0.08 \mathrm{~ms}, p<0.03 ; n=8$ ) (Fig. $5 A$, No drug). To further confirm the blocking effect of intracellular $\mathrm{A} \beta_{1-42}$ on $\mathrm{BK}$ channels, the $\mathrm{BK}$ channel opener isopimaric acid was bath applied (Fig. $5 B$, Iso). Indeed, this drug blocked the effect of $A \beta_{1-42}$ on spike width in rat neocortical neurons. With $10 \mu \mathrm{M}$ isopimaric acid, spike half-width in $\mathrm{A} \beta_{1-42}$-injected neurons (first spike, $1.26 \pm 0.03 \mathrm{~ms}$; fourth spike, $1.38 \pm 0.04 \mathrm{~ms} ; n=4$ ) was reduced to the same level as in $\mathrm{A} \beta_{1-40}$-injected neurons (first spike, $1.27 \pm$ $0.03 \mathrm{~ms}$; fourth spike, $1.34 \pm 0.07 \mathrm{~ms} ; n=4$ ) or control neurons (first spike, $1.28 \pm 0.06 \mathrm{~ms}$; fourth spike, $1.40 \pm 0.09 \mathrm{~ms} ; n=4$ ).

We have previously reported that electroconvulsive shock (ECS) facilitates BK channel opening by expression of Homerla and that the downstream signaling of Homerla involves metabotropic glutamate receptors (mGluRs) and inositol-1,4,5- trisphosphate (Ango et al., 2001; Sakagami et al., 2005). We therefore tested whether this ECS-induced activation of BK channels counteracts the blocking effect of $\mathrm{A} \beta_{1-42}$ on these channels. This was found true, because in slices from rats subjected to ECS (Fig. $5 A, B, \mathrm{ECS}$ ), spike half-width in $\mathrm{A} \beta_{1-42}$-injected neurons (first spike, $1.10 \pm 0.03 \mathrm{~ms}$; fourth spike, $1.26 \pm 0.05 \mathrm{~ms} ; n=5$ ) was shortened to the same level as in control neurons (first spike, $1.11 \pm 0.04 \mathrm{~ms}$; fourth spike, $1.23 \pm 0.09 \mathrm{~ms} ; n=6$ ) or $\mathrm{A} \beta_{1-40^{-}}$ injected neurons (first spike, $1.12 \pm 0.05 \mathrm{~ms}$; fourth spike, $1.27 \pm$ $0.07 \mathrm{~ms} ; n=5)$. It is therefore suggested that, although intracellular $\mathrm{A} \beta_{1-42}$ suppresses $\mathrm{BK}$ channels, this suppression may be reversed by ECS-induced Homerla expression.

To test this hypothesis, we used HlaKO mice. We examined actions of $\mathrm{A} \beta$ in wild-type mice and HlaKO mice, which are so
C
Control Nimodipine Control CPA
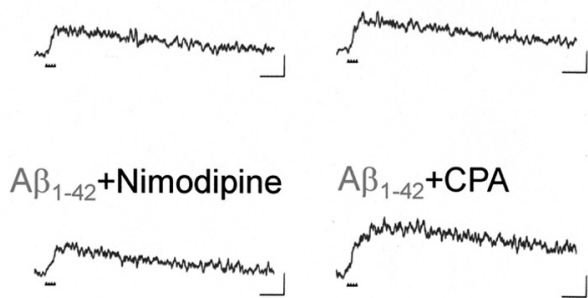

$\mathrm{D}$

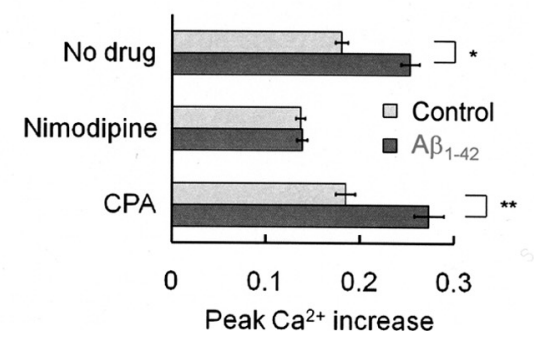

Figure 4. Failure of intracellular $A \beta_{1-42}$ to directly modulate $\mathrm{Ca}^{2+}$ channels. $\boldsymbol{A}, \mathrm{Ca}^{2+}$ currents with $1 \mu \mathrm{m} \mathrm{A} \beta_{1-42}(n=10)$ or without $A \beta_{1-42}$ (Control; $n=7$ ) infused. Calibration: $100 \mathrm{~ms}, 1 \mathrm{nA}$. B , The peak amplitude of $\mathrm{Ca}^{2+}$ current (elicited by voltage steps to $-50,-30,-10$, and $10 \mathrm{mV}$ ) was compared. $A \beta_{1-42}$ infusion has no effects on $\mathrm{Ca}^{2+}$ currents. $C$, The voltage-dependent ( Channel blocker nimodipine ( $20 \mu \mathrm{m}$; Control, $\left.n=5 ; \mathrm{A} \beta_{1-42}, n=5\right)$, but not the $\mathrm{Ca}^{2+}$ store depleter CPA (30 $\mu \mathrm{m}$; Control, stronger with $A \beta_{1-42}$, rather indirectly, because of $B K$ channel suppression by $A \beta_{1-42}$ (Fig. 3). Calibration: $500 \mathrm{~ms},-0.1 \Delta F_{380}$ $F_{360}$. D, Peak amplitude of spike-induced $\mathrm{Ca}^{2+}$ increases in the presence of nimodipine or CPA, indicating that $\mathrm{Ca}^{2+}$ release channels are not involved at all. ${ }^{*} p<0.001 ;{ }^{* *} p<0.01$.

designed that their neurons fail to express Homerla specifically but not Homer1b/c, the longer splice variant of Homer1 (Inoue et al., 2009). By varying stimulation parameters, we first attempted in mice to reproduce the spike broadening shown in rats so far. It was found that $\mathrm{A} \beta_{1-42}$-induced spike broadening is elicited by spike trains at $100 \mathrm{~Hz}$ and that trains of five spikes, rather than four, make spikes wider comparably to the data obtained from rats (Fig. 6, top). Spike half-width at the fifth spike in $\mathrm{A} \beta_{1-}$ 42-injected neurons ( $10 \mu \mathrm{M} ; 2.18 \pm 0.14 \mathrm{~ms} ; n=6)$ was significantly larger than in control neurons $(1.51 \pm 0.09 \mathrm{~ms} ; p<0.01$; $n=5)$ or $\mathrm{A} \beta_{1-40}$-injected neurons ( $1.53 \pm 0.17 \mathrm{~ms} ; p<0.02 ; n=$ 5) (Fig. $6 B$, top). The application of charybdotoxin significantly broadened spike half-width at the fifth spike even in control neurons $(2.01 \pm 0.11 \mathrm{~ms} ; p<0.02$ vs without $\mathrm{Chtx} ; n=4)$ and in $\mathrm{A} \beta_{1-40}$-injected neurons $(2.28 \pm 0.21 \mathrm{~ms} ; p<0.04$ vs without Chtx; $n=4)$, and the injection of $\mathrm{A} \beta_{1-42}$ did not increase spike half-width any longer $(2.18 \pm 0.22 \mathrm{~ms} ; n=5)$ (Fig. 6, middle). Moreover, application of isopimaric acid blocked spike broadening in $\mathrm{A} \beta_{1-42}$-injected neurons (fifth spike, $1.29 \pm 0.09 \mathrm{~ms} ; n=5$ ) (Fig. 6, bottom). Thus, as we observed in rats, charybdotoxin mimicked and occluded and isopimaric acid blocked the effect of $\mathrm{A} \beta_{1-42}$ in neurons from wild mice, suggesting that spike broadening was caused by the $\mathrm{A} \beta_{1-42}$-induced suppression of BK channels in wild mice as well.

We then checked whether these $\mathrm{A} \beta_{1-42}$-induced changes of spike width were blocked by ECS in wild mice. Indeed, in mice that underwent ECS, spike half-width during spike trains was not affected by $10 \mu \mathrm{M} \mathrm{A} \beta_{1-42}$ (Fig. 7, top). At the fifth spike, the spike half-width was $1.44 \pm 0.14 \mathrm{~ms}$ in $\mathrm{A} \beta_{1-42}$-infused neurons $(n=5)$, almost the same as $1.42 \pm 0.12 \mathrm{~ms}$ in control neurons $(n=4)$ and $1.29 \pm 0.10 \mathrm{~ms}$ in $\mathrm{A} \beta_{1-40}$-infused neurons $(n=5)$. On the other hand, in $\mathrm{H} 1 \mathrm{aKO}$ mice, ECS failed to block $\mathrm{A} \beta_{1-42}$-mediated spike 


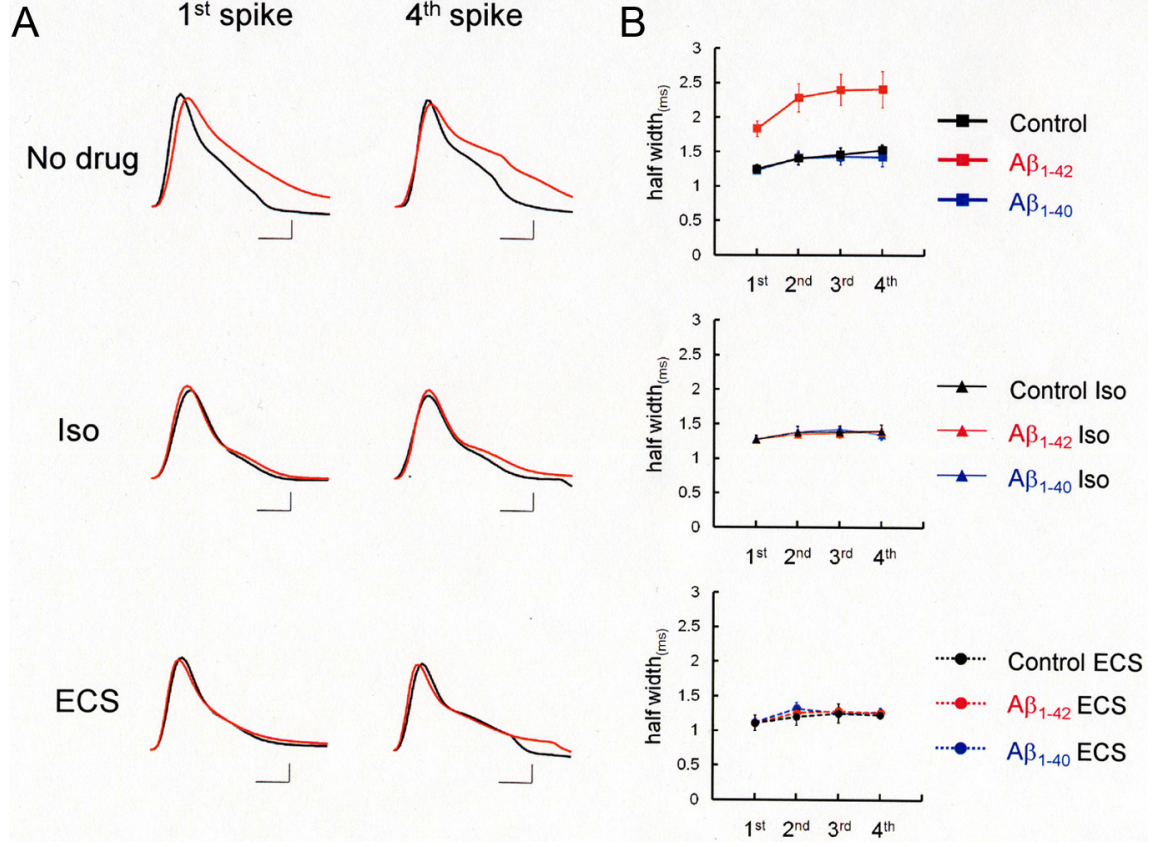

Figure 5. ECS blocked $A \beta_{1-42}$-mediated suppression of BK channels in rat neocortical neurons. $A$, First and fourth spike in spike trains under the application of the BK channel opener isopimaric acid (Iso; $10 \mu \mathrm{M}$ ) or after ECS, in a control neuron (black) and an $A \beta_{1-42}$-injected neuron (red). The same spike broadening as observed with fura- 2 was confirmed without fura- 2 in patch pipettes (Fig. 1). Note differences to the same extent in spike width between cells with (red line) and without intracellular $A \beta_{1-42}$ (black line, No drug). Both isopimaric acid and ECS prevented $A \beta_{1-42}$ from broadening spike width. Calibration: $1 \mathrm{~ms}, 20 \mathrm{mV}$. B, Averaged spike half-width during four-spike trains (black, Control; red, $A \beta_{1-42}$; blue, $A \beta_{1-40}$ ) with No drug (top), with Iso (middle), and after ECS (bottom). Each point is based on an average over four to eight trials.

broadening (Fig. 7, middle and bottom). The spike half-width at the fifth spike in $\mathrm{A} \beta_{1-42}$-infused neurons was $2.22 \pm 0.07 \mathrm{~ms}(n=5)$, still at the same level as without ECS $(2.39 \pm 0.11 \mathrm{~ms} ; n=4)$ (Fig. 7, middle), and significantly longer than in control neurons (1.12 \pm $0.08 \mathrm{~ms} ; p<0.0001 ; n=4)$ and $\mathrm{A} \beta_{1-40}$-infused neurons $(1.23 \pm 0.08$ ms; $p<0.0001 ; n=4$ ) (Fig. 7, bottom). These results indicates that the blocking effect of ECS on $\mathrm{A} \beta_{1-42}$ was absent in $\mathrm{H} 1 \mathrm{aKO}$ mice, suggesting that Homerla is a key protein that mediates counteraction by ECS against intracellular $\mathrm{A} \beta_{1-42}$-induced suppression of $\mathrm{BK}$ channels.

\section{$\mathrm{A} \boldsymbol{\beta}_{1-42}$-mediated suppression of BK channels is rescued by ECS via Homer la in young $3 \times \mathrm{Tg}$ mice}

It is shown that, in $3 x \operatorname{Tg} \mathrm{AD}$ model mice, prominent intracellular $\mathrm{A} \beta$ accumulation is apparent, precedes extracellular $A \beta$ formation at 3-4 months of age in the neocortex (Oddo et al., 2003), and causes early disease-related cognitive deficits (Billings et al., 2005). These findings raise the possibility that $\mathrm{A} \beta$-mediated suppression of $\mathrm{BK}$ channels we have observed in $\mathrm{A} \beta_{1-42}$-injected neurons represents an early pathophysiological manifestation of young $\mathrm{AD}$ model mice. To test this hypothesis, we examined whether, in neurons of 3xTg mice at 4 months of age, $\mathrm{A} \beta$-mediated suppression of $\mathrm{BK}$ channels was actually observed. In 3xTg mice, even without drugs or $\mathrm{A} \beta_{1-42}$ applied, spike broadening was observed similarly to those in $\mathrm{A} \beta_{1-42^{-}}$ infused neurons from wild mice; spike half-width at the fifth spike was significantly greater in $3 x T g$ mouse neurons $(2.36 \pm 0.18 \mathrm{~ms}$; $p<0.01 ; n=6$ ) than in controls from wild mice (Fig. 8, no drug). In contrast, spike broadening was not observed in neurons from juvenile $3 \times \mathrm{Tg}$ mice (16-18 d of age; $3 \times \mathrm{Xg}_{\mathrm{j}}$ ), in which intracellular $\mathrm{A} \beta$ accumulation has not yet occurred (Oddo et al., 2003). The spike half-width at the fifth spike in 3xTgj cells $(1.67 \pm 0.02 \mathrm{~ms} ; n=4)$ (Fig. 8 B, 3xTg ) was significantly smaller than in cells from 4 -month- old $3 x$ Tg mice $(2.36 \pm 0.18 \mathrm{~ms} ; p<0.02$; $n=6$ ) (Fig. $8 B$ ) but was not significantly different from that in wild controls $(1.51 \pm$ $0.09 \mathrm{~ms} ; n=5)$. It is thus demonstrated that the spike broadening is attributable to intracellular $\mathrm{A} \beta$, which is accumulated in $3 \mathrm{xTg}$ but not 3xTgj neurons. Finally, in 3xTgj neurons, extracellular application of $\mathrm{A} \beta$ failed to broaden spikes $(1.56 \pm 0.08 ; n=4)$ (Fig. $8 B, 3 \mathrm{xTg}_{\mathrm{j}}+$ extracellular $\mathrm{A} \beta$ ), precluding the possibility that extracellular $A \beta$ may be responsible for this phenomenon.

With the application of charybdotoxin in neurons from 4-month-old 3xTg mice, there was no further spike broadening (fifth spike, $2.14 \pm 0.24 \mathrm{~ms} ; n=4$ ) (Fig. 8, Chtx). These effects on spike width was blocked both by the application of isopimaric acid (fifth spike, $1.35 \pm 0.02 \mathrm{~ms}$; $n=4$ ) (Fig. 8 , Iso) and by ECS (fifth spike, $1.39 \pm 0.06 \mathrm{~ms} ; n=6$ ) (Fig. 8, ECS). These data suggest that $A \beta$-mediated suppression of BK channels actually occurs and is recovered by ECS in 3xTg mouse neurons, in which intracellular $A \beta$ is accumulated innately without any injection from patch pipettes. We then tested whether Homerla mediates this ECSinduced rescue of $\mathrm{A} \beta$-mediated suppression of BK channels in 3xTg mice. By applying anti-Homerla antibody $(0.4 \mu \mathrm{g} /$ $\mathrm{ml}$ ) into neurons by patch pipette (Ueta et al., 2008), spike width was examined. Consistently with our findings so far, antiHomerla antibody canceled out the effect of ECS in 3xTg mice; at the fifth spike, spike half-width was significantly larger $(2.16 \pm$ $0.17 \mathrm{~ms} ; p<0.01 ; n=7$ ) (Fig. 8, ECS HlaAb) than those in control neurons from wild mice. These recordings support the notion that ECS reversed $\mathrm{A} \beta$-mediated suppression of BK channels via Homerla expression in 3xTg mice.

Our experiments so far, which demonstrated a larger spike width in 3xTg neurons, were done in visual cortex slices. This finding was generalized by using frontal cortex slices from $3 \mathrm{xTg}$ mice. The spike half-width at the fifth spike was significantly greater in frontal cortex layer II/III pyramidal cells from 3xTg mice $(2.02 \pm 0.15 \mathrm{~ms} ; p<0.001 ; n=9)$ than in controls from wild mice ( $1.38 \pm 0.01 \mathrm{~ms} ; n=14)$, suggesting that the present findings can be fairly extended to cortical areas that are regarded to relate more intimately to $\mathrm{AD}$ symptoms than the visual cortex.

To confirm the suppression of BK channels in $3 \mathrm{xTg}$, we further conducted single BK current recording (Fig. 9). Also, rescue of suppressed BK channels was attempted by ECS in 3xTg mice. Single-channel currents were elicited in wild mouse neurons, either by ramp-voltage command from +100 to $-100 \mathrm{mV}$ (Fig. $9 A$ ) or by step command from 0 to $+40 \mathrm{mV}$ (Fig. $9 B$ ). In neurons from $3 x T g$ mice subjected to ECS, a similar channel activity was evoked by ramp command (Fig. 9, 3xTg ECS), whereas it was not in cells from naive $3 \mathrm{xTg}$ mice. Importantly, the BK channel blocker charybdotoxin abolished the channel activities in wild mouse neurons (Fig. 9, WT Chtx) as well as those from 3xTg mice subjected to ECS (Fig. 9, 3xTg ECS Chtx). This blockade indicates that the currents we recorded here are attributable to BK channel opening.

These findings were confirmed by recordings obtained by using rectangular voltage command, which exhibited positive all- 
or-none currents with large conductance in cells from wild mice and 3xTg mice after ECS (Fig. 9B). Open probabilities were significantly higher in neurons from $3 \mathrm{xTg}$ mice with ECS (Fig. 9C) (3xTg ECS, $p<$ $0.001)$ than without ECS $(3 \times \mathrm{Tg})$, which was canceled out by charybdotoxin (3xTg ECS Chtx). It is thus shown that $\mathrm{A} \beta_{1-42}$-induced suppression of $\mathrm{BK}$ channels is counteracted by ECStriggered Homerla expression in neurons from young $3 \mathrm{xTg} \mathrm{AD}$ model mice as well as in $\mathrm{A} \beta_{1-42}$-injected neurons from wild mice.

\section{Discussion}

The present study revealed that intracellularly injected $\mathrm{A} \beta_{1-42}$ downregulates $\mathrm{BK}$ channels and broadens spike width in neocortical pyramidal neurons of rats and wild mice, thereby increasing their excitability. BK channel suppression was confirmed by single-channel recording in young $3 \times \mathrm{Tg}$ mice, in which intracellular $\mathrm{A} \beta$ is innately expressed. By using $\mathrm{H} 1 \mathrm{aKO}$, we showed that ECS-expressed Homerla counteracts $A \beta$ induced BK channel suppression, demonstrating a therapeutic potential of Homerla against the early-phase $\mathrm{AD}$.

\section{Distinct effects of extracellular and intracellular $\mathrm{A} \boldsymbol{\beta}$}

In contrast to reported actions of extracellularly applied or secreted $A \beta$ on synaptic and intrinsic neuronal properties (Wang et al., 2000; Kamenetz et al., 2003; Snyder et al., 2005; Origlia et al., 2008; Abramov et al., 2009), no data to date have directly highlighted roles of intracellular $\mathrm{A} \beta$ in neuronal excitability. The present study has shown that intracellular $A \beta$ suppressed BK channels and thereby broadens spike width, which elongates the total depolarization time during a given spike train. L-type VDCCs are then activated for a longer time and allow more $\mathrm{Ca}^{2+}$ influx. By voltage-clamp recording, we ruled out direct enhancement of $\mathrm{Ca}^{2+}$ current by $\mathrm{A} \beta$. Given that extracellular $\mathrm{A} \beta$ modulates L-type VDCCs (Ueda et al., 1997; MacManus et al., 2000), intracellular and extracellular $\mathrm{A} \beta$ may have different actions on these channels. The resting intracellular $\mathrm{Ca}^{2+}$ level is shown elevated in 3xTg mice (Lopez et al., 2008), although our method is unlikely to detect a maintained elevation in baseline $\mathrm{Ca}^{2+}$ concentration.

The present $\mathrm{A} \beta$-induced $\mathrm{BK}$ channel suppression is demonstrated by artificial intracellular injection of $\mathrm{A} \beta$ and in 3xTg mice that artificially overproduce $A \beta$. However, intracellular $\mathrm{A} \beta_{42}$ and $\mathrm{A} \beta_{40}$ have been demonstrated in brains of $\mathrm{AD}$ patients (Gouras et al., 2000). Moreover, Steinerman et al. (2008)
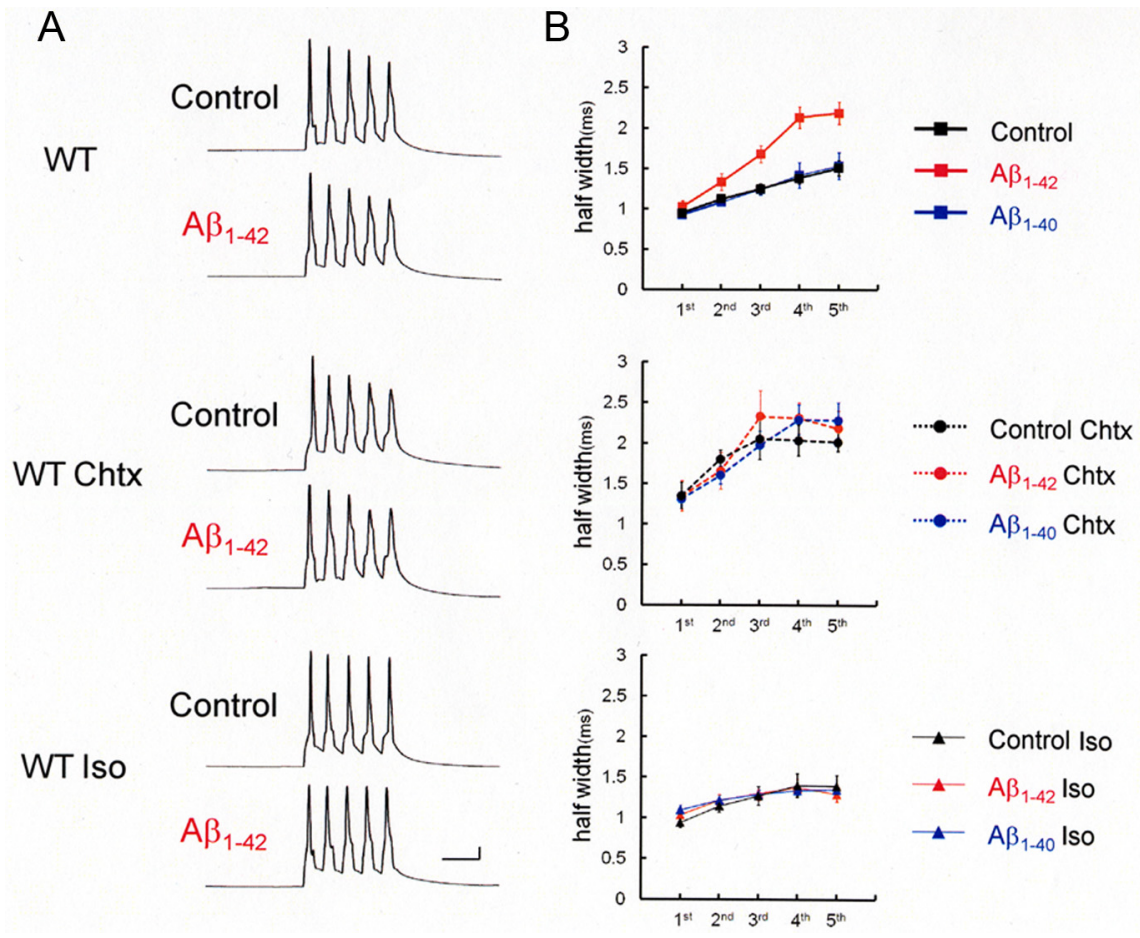

Figure 6. $A \beta_{1-42}$ injection into neurons in slices obtained from wild mice caused spike broadening. $A$, Recordings of spike trains induced by brief current injections at $100 \mathrm{~Hz}$ into neurons in slices obtained from wild mice. With $\mathrm{A} \beta_{1-42}$ injected intracellularly, spike half-widths in later spikes were significantly larger than in no- $\mathrm{A} \beta$ controls. Charybdotoxin mimics and occludes and Iso blocks the actions of $A \beta_{1-42}$, indicating that spike broadening is caused by $A \beta_{1-42}$-mediated blockade of $B K$ channels. Calibration: $20 \mathrm{~ms}, 20 \mathrm{mV}$. $\boldsymbol{B}$, Averaged spike half-width during the five-spike train (black, Control; red, $A \beta_{1-42}$; blue, $A \beta_{1-40}$ ) with no drug (top), with Chtx (middle), and with Iso (bottom). Each point is an average of four to six trials.

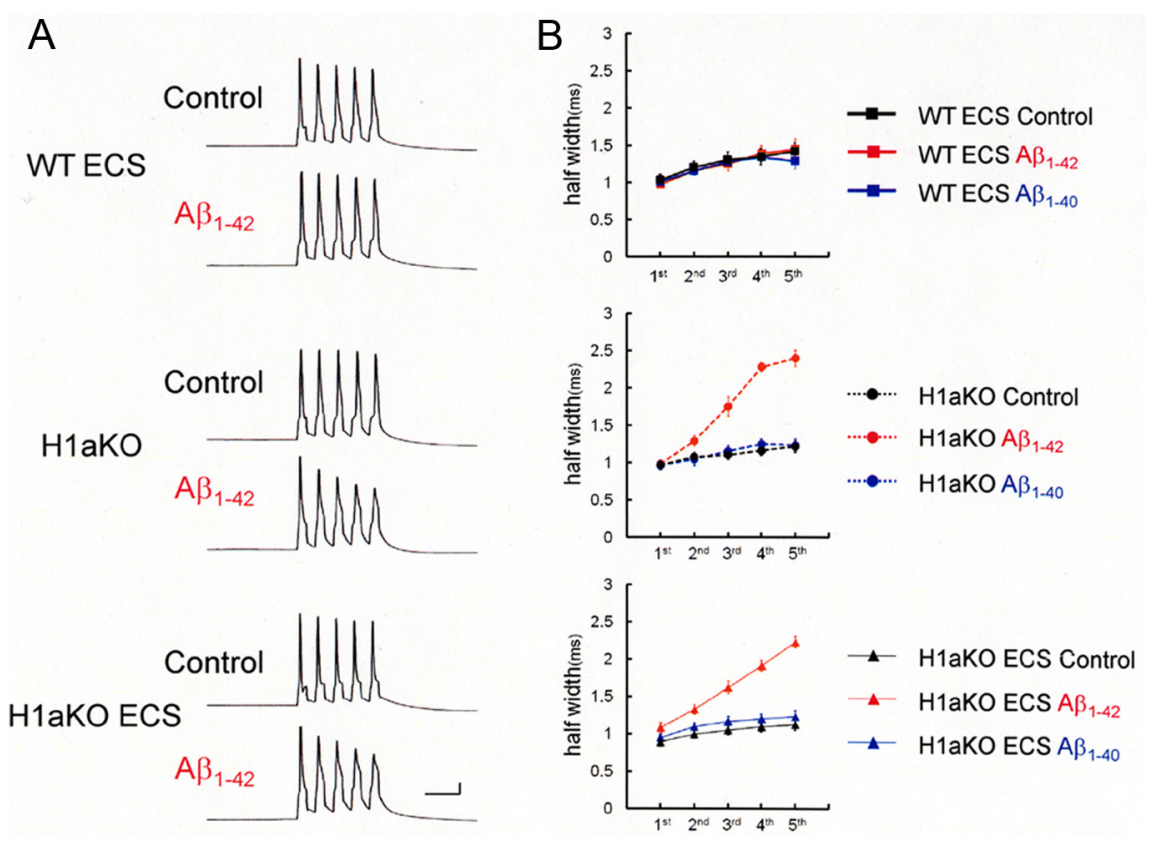

Figure 7. Blocking effects of ECS on $A \beta_{1-42}$ was absent in $\mathrm{H} 1$ aKO mice. $A$, ECS counteracts $A \beta_{1-42}$-mediated spike broadening in wild-type mice (WT ECS) but not in H1aKO mice (H1aKO, H1aKO ECS). Calibration: 20 ms, 20 mV. B, Averaged spike half-width during spike trains (black, Control; red, $A \beta_{1-42}$ ) with ECS in wild mice (top), without ECS in H1aKO mice (middle), and with ECS in H1aKO mice (bottom). Each point is an average of four to six trials. reported that intracellular and membrane-associated $A \beta$, especially $\mathrm{A} \beta_{42}$ in the temporal neocortex, may be more closely related to $\mathrm{AD}$ symptoms than other $\mathrm{A} \beta$ species that they examined. Although these authors did not attempt to describe the effects of 
A

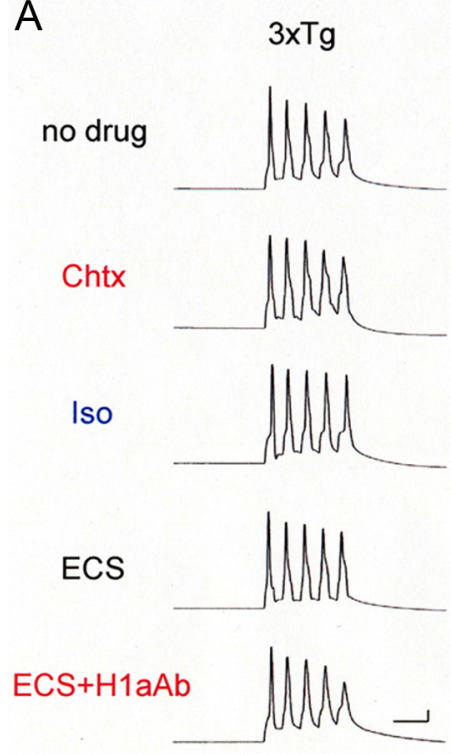

B
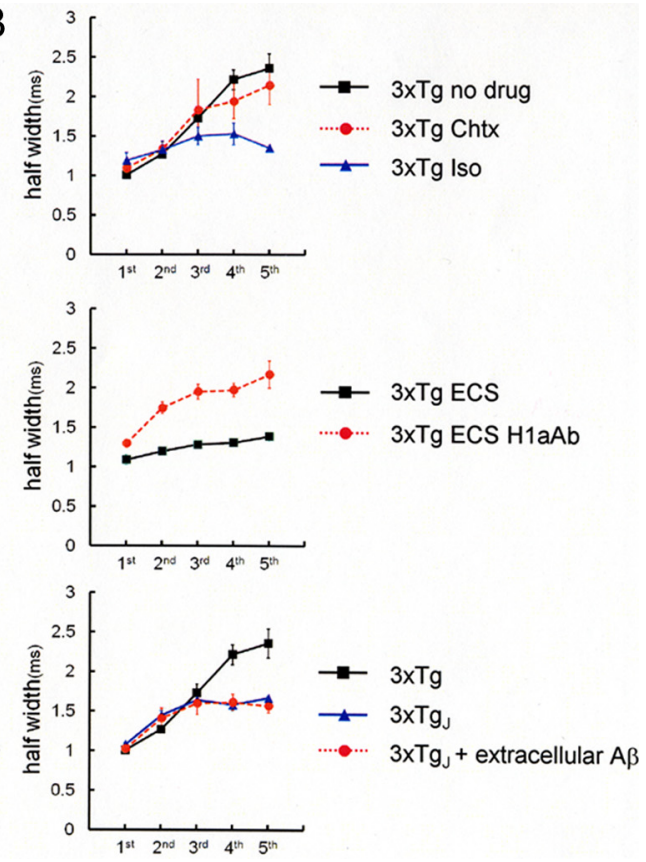

Figure 8. Spike broadening in $3 \times T g$ neurons. $A$, Recordings of spike trains in the $3 \times T g$ mice at 4 months of age, exhibiting spike broadening. The top recording shows spike broadening in the naive condition (no drug, $n=6$ ). The addition of charybdotoxin failed to broaden spikes further $(n=4)$, exhibiting occlusion of the blocker effect. Iso blocked the spike broadening $(n=4)$. The bottom two recordings show spike trains in neurons from 3xTg mice after ECS. ECS on 3xTg mice blocked the spike broadening, which was cancelled out by injection of anti-Homer1a antibody ( $0.4 \mu \mathrm{g} / \mathrm{ml} ; \mathrm{ECS}, n=6 \mathrm{vs} \mathrm{ECS}+\mathrm{H} 1 \mathrm{aAb}, n=7)$. Calibration: 20 $\mathrm{ms}, 20 \mathrm{mV}$. B, Averaged spike width in 3xTg cells. Top, Spike half-width is shown for naive 3xTg neurons (No drug; black square), those with BK channel blockade (Chtx; red circle), and those with Iso (blue triangle). Middle, Averaged spike half-width after ECS with $\mathrm{H} 1 \mathrm{aAb}$ (ECS + H1aAb; red circle) or without (ECS; black square). Bottom, Spike half-width recorded in neurons from juvenile $3 \times \operatorname{Tg}\left(16-18 \mathrm{~d}\right.$ old; $\left.3 \times \mathrm{Tg}_{\mathrm{j}}\right)$, in which intracellular $A \beta$ has not yet been accumulated. Spike width was smaller in $3 \times \mathrm{Tg}_{\mathrm{j}}$ neurons ( $3 \times \mathrm{Tg}_{j}$; blue triangle) than in $3 \times \mathrm{Tg}$ neurons (3xTg; black square) and remained at a range comparable with that in wild controls. Extracellular application of $A \beta_{1-42}(1 \mu \mathrm{m})$ to $3 \times \mathrm{Tg}_{\mathrm{j}}$ cells failed to broaden spikes ( $3 \times \mathrm{Tg}_{\mathrm{j}}+$ extracellular $\mathrm{A} \beta$; red circle).

A

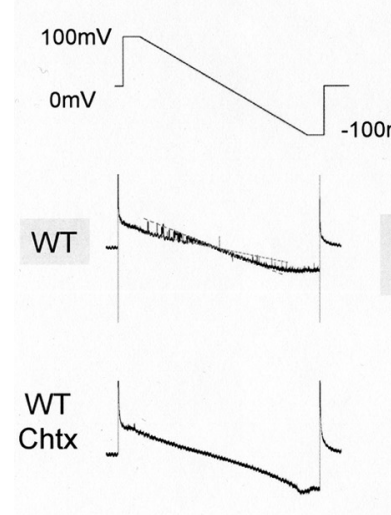

$3 \times T g$
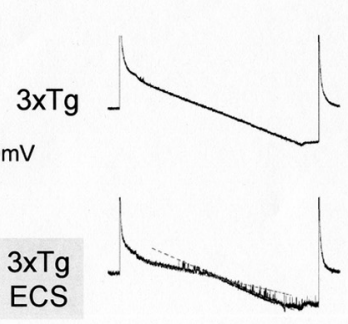

$3 \times T g$
ECS
Chtx

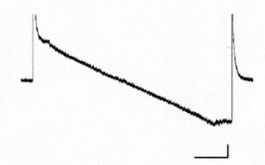

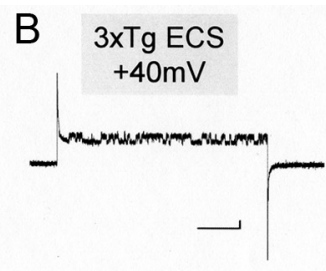

C

\begin{tabular}{lc}
\hline & $P_{0}$ at $+40 \mathrm{mV}$ \\
\hline WT & $0.44 \pm 0.09$ \\
WT Chtx & $0.01 \pm 0.01$ \\
3XTg & $0.00 \pm 0.00$ \\
3xTg ECS & $0.40 \pm 0.11$ \\
3xTg ECS Chtx & $0.00 \pm 0.00$ \\
\hline
\end{tabular}

Figure 9. Recovery of single BK current by ECS in 3xTg mice. $A$, A ramp-voltage command from +100 to $-100 \mathrm{mV}$ (top left) induces single BK currents in wild mice (WT; $n=6)$ and $3 \times \operatorname{Tg}$ mice after $\mathrm{ECS}(3 \mathrm{xTg} \mathrm{ECS} ; n=5)$, but not in $3 \times \mathrm{Tg}$ mice without ECS ( $3 x \operatorname{Tg} ; n=6)$. These single currents were blocked by Chtx ( $n=5 ; 3 x \operatorname{Tg}$ ECS Chtx, $n=4)$. The dotted lines indicate the open or closed states. Calibration: $200 \mathrm{~ms}, 10$ pA. B, Single BK currents were confirmed by a rectangle voltage command from 0 to $+40 \mathrm{mV}$ in $3 \times \mathrm{Tg}$ mice after ECS. This voltage step was used, since the open probability hereby was found close to $\sim 50 \%$. Calibration: $200 \mathrm{~ms}, 5 \mathrm{pA}$. C, Open probability (Po) based on recordings with step commands to +40 $\mathrm{mV}$. Each point is an average of four to six trials.

monomers and oligomers differentially, the presence of intracellular $\mathrm{A} \beta_{42}$ has been clearly demonstrated in diseased human brains. This demonstration seems to argue against the possibilities that the present finding obtained by intracellularly injecting a mixed preparation of $\mathrm{A} \beta_{42}$ consisting of oligomers and mono-

mers is merely artifactual, and that intracellular $\mathrm{A} \beta$ may be characteristic just to genetically modified mice.

Intraneuronal $A \beta$ is present both in late endosome (Takahashi et al., 2002) and cytoplasm (LaFerla et al., 2007). The present results obtained with $\mathrm{A} \beta_{42}$ injection depends on cytoplasmic $\mathrm{A} \beta_{42}$. Although the same $\mathrm{BK}$ channel suppression and ECS sensitivity was observed in $\mathrm{A} \beta_{42^{-}}$ injected wild neurons and in $3 \times \mathrm{xTg}$ neurons, the possibility still remains that some $3 \times \mathrm{xTg}$ data might be at least partly caused by endosomal A $\beta$. Since extracellular $\mathrm{A} \beta$ affects glutamate receptor trafficking (Snyder et al., 2005; Hsieh et al., 2006), which is largely an intracellular event, $A \beta$-triggered signals should be mediated inside. An obvious possibility is that extracellular $\mathrm{A} \beta$ interacts with surface receptors like nicotinic acetylcholine receptors and then transmembrane signals are generated (Wang et al., 2000; Snyder et al., 2005; Gu et al., 2009; Laurén et al., 2009). Another possibility is a transmembrane transport of $A \beta$, given that $A \beta$ can be internalized by RAGE and transported across the blood-brain barrier by means of RAGE-mediated internalization (Deane et al., 2003). Such transmembrane transport might occur on endosomes as well, then cytosolic and endoplasmic $A \beta$ could be more interchangeable than currently understood.

$\mathrm{A} \beta$ is known to exist in several multimer states, and this multiplicity determines its toxicity (for review, see LaFerla et al., 2007). Oddo et al. (2006) showed that neurons from 6-month-old 3xTg are positive in immunostaining for $A \beta$ oligomer larger than 12-24mer, whereas those from 4-monthold $3 \times \mathrm{Tg}$ are not. Therefore, the present demonstration of BK channel suppression in 4-month-old 3xTg is most likely attributable to $A \beta$ monomer or oligomer smaller than $12 \mathrm{mer}$, suggesting that these species of $\mathrm{A} \beta_{1-42}$ may have also caused the $\mathrm{BK}$ channel suppression with $\mathrm{A} \beta_{1-42}$ injection. The present gel electrophoresis showed that the injected $\mathrm{A} \beta_{1-42}$, but not $\mathrm{A} \beta_{1-40}$, contains trimer and tetramer (Fig. 2). Therefore, the present experiments with intracellular injection of $\mathrm{A} \beta_{1-42}$ suggest that lowmolecular-weight oligomers or monomers of $A \beta_{1-42}$ affect $B K$ channels, whereas no conclusion can be drawn regarding higher-order oligomers as they have not been tested.

Damages expected by $\mathrm{BK}$ channel suppression in $\mathrm{AD}$ brains It is widely considered that $\mathrm{BK}$ channel suppression is deleterious to neuron survival (Liu et al., 1999; Hu et al., 2001; Williams et al., 2004; Yu et al., 2010). The present study showed that BK channels 
are suppressed by intracellular $A \beta$, which broadened spike width and promoted spike-induced $\mathrm{Ca}^{2+}$ entry from $\mathrm{Ca}^{2+}$ channels. Normally, BK channels are activated by $\mathrm{Ca}^{2+}$ entry, repolarize spikes rapidly, and prevent further voltage-dependent $\mathrm{Ca}^{2+}$ entry, thus forming a negative feedback loop (Hu et al., 2001). $\mathrm{A} \beta$-induced $\mathrm{BK}$ channel suppression would halt this negativefeedback mechanism, thus perturbing $\mathrm{Ca}^{2+}$ homeostasis in disfavor of neuron survival. Hu et al. (2001) also proposed that, unlike somatic BK channels, presynaptic BK channels participate in such a feedback regulation in pathological conditions like hyperactivity, excitotoxicity, and cell death. Such "emergency brake" mechanisms of BK channels (Hu et al., 2001) may be negated in the $\mathrm{AD}$ brain. Crucial roles of $\mathrm{BK}$ channel-mediated mechanisms are emphasized also in excitability regulation at the axon initial segment and glutamate release from the synaptic terminal in cortical pyramidal cells (Yu et al., 2010). BK channel suppression would induce neuronal hyperexcitability and excessive glutamate release, thus leading to excitotoxic neuronal damage. Extracellular application of soluble $\mathrm{A} \beta$ is reported to cause $\mathrm{Ca}^{2+}$ entry in neurons, which may produce mitochondrial $\mathrm{Ca}^{2+}$ overload and lead to neuron death (Sanz-Blasco et al., 2008). The same damage may occur with an increase in $\mathrm{Ca}^{2+}$ entry caused by intracellular $\mathrm{A} \beta$.

BK channels are crucially involved in oxygen sensing in the carotid body chemoreceptors (Williams et al., 2004), in which the oxygen sensor hemoxyenase-2 associates tightly with BK channels. Interestingly, this association occurs not just with native, but also with recombinant, BK channels. The possibility, therefore, arises that BK channels expressed in central neurons may also sense local oxygen. In fact, a previous report showed that BK channel opening in mouse neocortical neurons is sensitive to hypoxic condition in a manner dependent on cytosolic factors (Liu et al., 1999). It is therefore possible that BK channel suppression by intracellular $A \beta$ hinders local oxygen-sensing mechanisms in neocortical neurons, rendering the $\mathrm{AD}$ brain more vulnerable to hypoxic insults. All these works point to exacerbating effects of the $\mathrm{A} \beta$-induced $\mathrm{BK}$ channel suppression on neuronal degeneration in the $\mathrm{AD}$ brain.

\section{Homerla counteracts BK channel suppression by intracellular $\mathbf{A} \boldsymbol{\beta}$}

Homerla is a member of the scaffold protein family Homerl that links membrane-embedded receptors like mGluRs and other scaffold proteins like Shank (Brakeman et al., 1997; Kato et al., 1997). Homerl consists of the constitutively expressed Homerlb/c, which can dimerize with each other, and activity-dependently induced Homerla, which misses the dimerizing motif and therefore acts as the negative regulator of Homer $1 \mathrm{~b} / \mathrm{c}$. Homerla is also known to activate group I mGluRs from inside the neuron as if it were an "intracellular ligand" (Ango et al., 2001). By intracellularly injecting Homer1a in neocortex pyramidal cells, we have previously revealed that activation of mGluRs by Homerla leads to facilitation of BK channels, thereby reducing neuronal excitability (Sakagami et al., 2005). Homerla is expressed after strong stimulation such as LTP-inducing tetanization or flashing light (Brakeman et al., 1997; Kato et al., 1997). We confirmed that whole-brain activation by ECS, the animal model of electroconvulsive therapy (ECT) used for depression, can induce Homerla expression and facilitate BK channels, depending on Homerla expression (Sakagami et al., 2005; Kato, 2009). Various lines of evidence support involvement of this and other Homer species in neuropsychiatric disorders (Szumlinski et al., 2006).
The present study successfully demonstrated that this Homerlainduced facilitation of $\mathrm{BK}$ channels reactivates $\mathrm{A} \beta$-suppressed BK channels in neocortex pyramidal cells. We did two separate sets of experiments in $\mathrm{H} 1 \mathrm{aKO}$ and 3xTg mice. In H1aKO mice, ECS could not induce Homerla and failed to counteract BK channel suppression induced by intracellular $\mathrm{A} \beta$. In $3 \times \mathrm{Tg}$ mice, we confirmed that BK channels are suppressed by innately expressed intracellular $A \beta$. Then we revealed that ECS induces Homerla expression and thereby reactivates $\mathrm{A} \beta$-suppressed $\mathrm{BK}$ channels, since this ECS effect was prevented by intracellularly injected anti-Homerla antibody.

The present findings suggest that Homerla expression would be a therapeutic measure against at least one aspect of $A \beta$ toxicity at the early stage of AD. Although ECT could be useful to induce Homerla expression, especially promising may be transcranial magnetic stimulation (TMS), a noninvasive milder version of ECT that has been used safely for treatment of major depression or for research on cognitive function (O'Reardon et al., 2007; Rossi et al., 2009). In fact, TMS-induced improvement of action naming, a cognitive task, in $\mathrm{AD}$ patients has been reported (Cotelli et al., 2006). Molecular and cellular underpinnings of this cognitive improvement are not known at all, although the present study suggests that the anticipated Homerla expression by TMS may be involved.

\section{References}

Abramov E, Dolev I, Fogel H, Ciccotosto GD, Ruff E, Slutsky I (2009) Amyloid- $\beta$ as a positive endogenous regulator of release probability at hippocampal synapses. Nat Neurosci 12:1567-1576.

Ango F, Prézeau L, Muller T, Tu JC, Xiao B, Worley PF, Pin JP, Bockaert J, Fagni L (2001) Agonist-independent activation of metabotropic glutamate receptors by the intracellular protein Homer. Nature 411:962-965.

Billings LM, Oddo S, Green KN, McGaugh JL, LaFerla FM (2005) Intraneuronal $\mathrm{A} \beta$ causes the onset of early Alzheimer's disease-related cognitive deficits in transgenic mice. Neuron 45:675-688.

Brakeman PR, Lanahan AA, O’Brien R, Roche K, Barnes CA, Huganir RL, Worley PF (1997) Homer: a protein that selectively binds metabotropic glutamate receptors. Nature 386:284-288.

Cirrito JR, Yamada KA, Finn MB, Sloviter RS, Bales KR, May PC, Schoepp DD, Paul SM, Mennerick S, Holtzman DM (2005) Synaptic activity regulates interstitial fluid amyloid- $\beta$ levels in vivo. Neuron 48:913-922.

Cotelli M, Manenti R, Cappa SF, Geroldi C, Zanetti O, Rossini PM, Miniussi C (2006) Effect of transcranial magnetic stimulation on action naming in patients with Alzheimer disease. Arch Neurol 63:1602-1604.

Deane R, Du Yan S, Submamaryan RK, LaRue B, Jovanovic S, Hogg E, Welch D, Manness L, Lin C, Yu J, Zhu H, Ghiso J, Frangione B, Stern A, Schmidt AM, Armstrong DL, Arnold B, Liliensiek B, Nawroth P, Hofman F, et al. (2003) RAGE mediates amyloid- $\beta$ peptide transport across the bloodbrain barrier and accumulation in brain. Nat Med 9:907-913.

Faber ES, Sah P (2003) $\mathrm{Ca}^{2+}$-activated $\mathrm{K}^{+}$(BK) channel inactivation contributes to spike broadening during repetitive firing in the rat lateral amygdala. J Physiol 552:483-497.

Ferreri F, Pauri F, Pasqualetti P, Fini R, Dal Forno G, Rossini PM (2003) Motor cortex excitability in Alzheimer's disease: a transcranial magnetic stimulation study. Ann Neurol 53:102-108.

Gouras GK, Tsai J, Naslund J, Vincent B, Edgar M, Checler F, Greenfield JP, Haroutunian V, Buxbaum JD, Xu H, Greengard P, Relkin NR (2000) Intraneuronal $A \beta 42$ accumulation in human brain. Am J Pathol 156:15-20.

Gu Z, Liu W, Yan Z (2009) $\beta$-Amyloid impairs AMPA receptor trafficking and function by reducing $\mathrm{Ca}^{2+} /$ calmodulin-dependent protein kinase II synaptic distribution. J Biol Chem 284:10639-10649.

Hardy J, Selkoe DJ (2002) The amyloid hypothesis of Alzheimer's disease: progress and problems on the road to therapeutics. Science 297:353-356.

Hsia AY, Masliah E, McConlogue L, Yu GQ, Tatsuno G, Hu K, Kholodenko D, Malenka RC, Nicoll RA, Mucke L (1999) Plaque-independent disruption of neural circuits in Alzheimer's disease mouse models. Proc Natl Acad Sci U S A 96:3228-3233.

Hsieh H, Boehm J, Sato C, Iwatsubo T, Tomita T, Sisodia S, Malinow R 
(2006) AMPAR removal underlies A $\beta$-induced synaptic depression and dendritic spine loss. Neuron 52:831-843.

Hu H, Shao LR, Chavoshy S, Gu N, Trieb M, Behrens R, Laake P, Pongs O, Knaus HG, Ottersen OP, Storm JF (2001) Presynaptic $\mathrm{Ca}^{2+}$-activated $\mathrm{K}^{+}$channels in glutamatergic hippocampal terminals and their role in spike repolarization and regulation of transmitter release. J Neurosci 21:9585-9597.

Inoue N, Nakao H, Migishima R, Hino T, Matsui M, Hayashi F, Nakao K, Manabe T, Aiba A, Inokuchi K (2009) Requirement of the immediate early gene vesl-1S/homer-1a for fear memory formation. Mol Brain $5: 2-7$.

Isomura Y, Kato N (1999) Action potential-induced dendritic calcium dynamics correlated with synaptic plasticity in developing hippocampal pyramidal cells. J Neurophysiol 82:1993-1999.

Kamenetz F, Tomita T, Hsieh H, Seabrook G, Borchelt D, Iwatsubo T, Sisodia S, Malinow R (2003) APP processing and synaptic function. Neuron 37:925-937.

Kato A, Ozawa F, Saitoh Y, Hirai K, Inokuchi K (1997) Vesl, a gene encoding VASP/Ena family related protein, is upregulated during seizure, longterm potentiation and synaptogenesis. FEBS Lett 412:183-189.

Kato N (2009) Neurophysiological mechanisms of electroconvulsive therapy for depression. Neurosci Res 64:3-11.

LaFerla FM, Green KN, Oddo S (2007) Intracellular amyloid- $\beta$ in Alzheimer's disease. Nat Rev Neurosci 8:499-509.

Laurén J, Gimbel DA, Nygaard HB, Gilbert JW, Strittmatter SM (2009) Cellular prion protein mediates impairment of synaptic plasticity by amyloid- $\beta$ oligomers. Nature 457:1128-1132.

Liu H, Moczydlowski E, Haddad GG (1999) $\mathrm{O}_{2}$ deprivation inhibits $\mathrm{Ca}^{2+}$ activated $\mathrm{K}^{+}$channels via cytosolic factors in mice neocortical neurons. J Clin Invest 104:577-588.

Llinás R, Sugimori M, Simon SM (1982) Transmission by presynaptic spike-like depolarization in the squid giant synapse. Proc Natl Acad Sci U S A 79:2415-2419.

Lopez JR, Lyckman A, Oddo S, Laferla FM, Querfurth HW, Shtifman A (2008) Increased intraneuronal resting $\left[\mathrm{Ca}^{2+}\right]$ in adult Alzheimer's disease mice. J Neurochem 105:262-271.

MacManus A, Rams den M, Murray M, Henderson Z, Pearson HA, Campbell VA (2000) Enhancement of ${ }^{45} \mathrm{Ca}^{2+}$ influx and voltage-dependent $\mathrm{Ca}^{2+}$ channel activity by $\beta$-amyloid-(1-40) in rat cortical synaptosomes and cultured cortical neurons. Modulation by the proinflammatory cytokine interleukin-1 $\beta$. J Biol Chem 275:4713-4718.

Moreno H, Yu E, Pigino G, Hernandez AI, Kim N, Moreira JE, Sugimori M, Llinás RR (2009) Synaptic transmission block by presynaptic injection of oligomeric amyloid beta. Proc Natl Acad Sci U S A 106:5901-5906.

Oddo S, Caccamo A, Shepherd JD, Murphy MP, Golde TE, Kayed R, Metherate R, Mattson MP, Akbari Y, LaFerla FM (2003) Triple-transgenic model of Alzheimer's disease with plaques and tangles: intracellular $\mathrm{A} \beta$ and synaptic dysfunction. Neuron 39:409-421.

Oddo S, Caccamo A, Tran L, Lambert MP, Glabe CG, Klein WL, LaFerla FM (2006) Temporal profile of amyloid- $\beta(\mathrm{A} \beta$ ) oligomerization in an in vivo model of Alzheimer disease. A link between $\mathrm{A} \beta$ and tau pathology. J Biol Chem 281:1599-1604.

O’Reardon JP, Solvason HB, Janicak PG, Sampson S, Isenberg KE, Nahas Z McDonald WM, Avery D, Fitzgerald PB, Loo C, Demitrack MA, George MS, Sackeim HA (2007) Efficacy and safety of transcranial magnetic stimulation in the acute treatment of major depression: a multisite randomized controlled trial. Biol Psychiatry 62:1208-1216.

Origlia N, Righi M, Capsoni S, Cattaneo A, Fang F, Stern DM, Chen JX, Schmidt AM, Arancio O, Yan SD, Domenici L (2008) Receptor for advanced glycation end product-dependent activation of $\mathrm{p} 38$ mitogenactivated protein kinase contributes to amyloid- $\beta$-mediated cortical synaptic dysfunction. J Neurosci 28:3521-3530.

Rogaeva E, Meng Y, Lee JH, Gu Y, Kawarai T, Zou F, Katayama T, Baldwin CT, Cheng R, Hasegawa H, Chen F, Shibata N, Lunetta KL, PardossiPiquard R, Bohm C, Wakutani Y, Cupples LA, Cuenco KT, Green RC, Pinessi L, et al. (2007) The neuronal sortilin-related receptor SORL1 is genetically associated with Alzheimer disease. Nat Genet 39:168-177.

Rossi S, Hallett M, Rossini PM, Pascual-Leone A (2009) Safety of TMS Consensus Group: Safety, ethical considerations, and application guidelines for the use of transcranial magnetic stimulation in clinical practice and research. Clin Neurophysiol 120:2008-2039.

Sakagami Y, Yamamoto K, Sugiura S, Inokuchi K, Hayashi T, Kato N (2005)
Essential roles of Homer-1a in homeostatic regulation of pyramidal cell excitability: a possible link to clinical benefits of electroconvulsive shock. Eur J Neurosci 21:3229-3239.

Sanz-Blasco S, Valero RA, Rodríguez-Crespo I, Villalobos C, Núñez L (2008) Mitochondrial $\mathrm{Ca}^{2+}$ overload underlies $\mathrm{A} \beta$ oligomers neurotoxicity providing an unexpected mechanism of neuroprotection by NSAIDs. PLoS One 3:e2718

Schägger H (2006) Tricine-SDS-PAGE. Nat Protocol 1:16-22.

Shao LR, Halvorsrud R, Borg-Graham L, Storm JF (1999) The role of BKtype $\mathrm{Ca}^{2+}$-dependent $\mathrm{K}^{+}$channels in spike broadening during repetitive firing in rat hippocampal pyramidal cells. J Physiol 521:135-146.

Snyder EM, Nong Y, Almeida CG, Paul S, Moran T, Choi EY, Nairn AC, Salter MW, Lombroso PJ, Gouras GK, Greengard P (2005) Regulation of NMDA receptor trafficking by amyloid- $\beta$. Nat Neurosci 8:1051-1058.

Steinerman JR, Irizarry M, Scarmeas N, Raju S, Brandt J, Albert M, Blacker D, Hyman B, Stern Y (2008) Distinct pools of $\beta$-amyloid in Alzheimer disease-affected brain: a clinicopathologic study. Arch Neurol 65:906-912.

Stine WB, Dahlgren KN, Krafft GA, LaDu MJ (2003) In vitro characterization of conditions for amyloid- $\beta$ peptide oligomerization and fibrillogenesis. J Biol Chem 278:11612-11622.

Szumlinski KK, Kalivas PW, Worley PF (2006) Homer proteins: implications for neuropsychiatric disorders. Curr Opin Neurobiol 16:251-257.

Takahashi RH, Milner TA, Li F, Nam EE, Edgar MA, Yamaguchi H, Beal MF, Xu H, Greengard P, Gouras GK (2002) Intraneuronal Alzheimer A $\beta 42$ accumulates in multivesicular bodies and is associated with synaptic pathology. Am J Pathol 161:1869-1879.

Ueda K, Shinohara S, Yagami T, Asakura K, Kawasaki K (1997) Amyloid $\beta$ protein potentiates $\mathrm{Ca}^{2+}$ influx through L-type voltage-sensitive $\mathrm{Ca}^{2+}$ channels: a possible involvement of free radicals. J Neurochem 68:265-271.

Ueta Y, Yamamoto R, Sugiura S, Inokuchi K, Kato N (2008) Homer la suppresses neocortex long-term depression in a cortical layer-specific manner. J Neurophysiol 99:950-957.

Walsh DM, Klyubin I, Fadeeva JV, Cullen WK, Anwyl R, Wolfe MS, Rowan MJ, Selkoe DJ (2002) Naturally secreted oligomers of amyloid $\beta$ protein potently inhibit hippocampal long-term potentiation in vivo. Nature 416:535-539.

Wang HY, Lee DH, D'Andrea MR, Peterson PA, Shank RP, Reitz AB (2000) $\beta$-Amyloid ${ }_{1-42}$ binds to alpha7 nicotinic acetylcholine receptor with high affinity. Implications for Alzheimer's disease pathology. J Biol Chem 275:5626-5632

Wei W, Nguyen LN, Kessels HW, Hagiwara H, Sisodia S, Malinow R (2010) Amyloid beta from axons and dendrites reduces local spine number and plasticity. Nat Neurosci 13:190-196.

Williams SE, Wootton P, Mason HS, Bould J, Iles DE, Riccardi D, Peers C, Kemp PJ (2004) Hemoxygenase-2 is an oxygen sensor for a calciumsensitive potassium channel. Science 306:2093-2097.

Yamada S, Takechi H, Kanchiku I, Kita T, Kato N (2004) Smallconductance $\mathrm{Ca}^{2+}$-dependent $\mathrm{K}^{+}$channels are the target of spikeinduced $\mathrm{Ca}^{2+}$ release in a feedback regulation of pyramidal cell excitability. J Neurophysiol 91:2322-2329.

Yamamoto K, Hashimoto K, Isomura Y, Shimohama S, Kato N (2000) An IP3-assisted form of $\mathrm{Ca}^{2+}$-induced $\mathrm{Ca}^{2+}$ release in neocortical neurons. Neuroreport 11:535-539.

Yamamoto K, Hashimoto K, Nakano M, Shimohama S, Kato N (2002a) A distinct form of calcium release down-regulates membrane excitability in neocortical pyramidal cells. Neuroscience 109:665-676.

Yamamoto K, Nakano M, Hashimoto K, Shimohama S, Kato N (2002b) Emergence of a functional coupling between inositol-1,4,5-trisphosphate receptors and calcium channels in developing neocortical neurons. Neuroscience 109:677-685.

Yamamoto K, Sakagami Y, Sugiura S, Inokuchi K, Shimohama S, Kato N (2005) Homer la enhances spike-induced calcium influx via L-type calcium channels in neocortex pyramidal cells. Eur J Neurosci 22:1338-1348.

Yang L, Wang Z, Wang B, Justice NJ, Zheng H (2009) Amyloid precursor protein regulates Cav1.2 L-type calcium channel levels and function to influence GABAergic short-term plasticity. J Neurosci 29:15660-15668.

Yu Y, Maureira C, Liu X, McCormick D (2010) P/Q and N channels control baseline and spike-triggered calcium levels in neocortical axons and synaptic boutons. J Neurosci 30:11858-11869. 